\title{
ELSŐDLEGES ÉRZELMEK MÉRÉSE AFFEKTÍV IDEGTUDOMÁNYI MEGKÖZELÍTÉSBEN: MÓDSZERTANI ÁTTEKINTÉS
}

\author{
DEÁK ANITA \\ Pécsi Tudományegyetem, Pszichológiai Intézet \\ E-mail: deak.anita@pte.hu \\ Benyújtva: 2020. március 4. - Elfogadva: 2020. május 9.
}

\begin{abstract}
Áttekintô tanulmányunkban a személyiségvonások érzelmi alapjaival foglalkozunk affektív idegtudományi megközelítésben. Összefoglaljuk azokat a kutatási eredményeket, amelyek a kéreg alatti agyi struktúrákhoz köthetô elsôdleges érzelmi rendszerek mérésével kapcsolatban születtek. Az Affektív idegtudományi személyiség skálák (Affective Neuroscience Personality Scales - ANPS) hat $(+1)$ érzelmi vonás mérésére szolgálnak (FÉLELEM, HARAG, SZOMORÚSÁG, JÁTÉKOSSÁG, KERESÉS, GONDOSKODÁS, Spiritualitás).

Módszer: Tanulmányunk alapját 65, 2003-2019 között publikált empirikus kutatás adja. Ezek mindegyikében adatgyújtés történt az ANPS kérdốivvel. A forrásokat négy csoportra osztottuk: validálási tanulmányok, biológiai markerekre hivatkozó tanulmányok, klinikai jellegú cikkek és egyéb, a széles körü alkalmazhatóságot igazoló publikációk. Jelen tanulmányban a validálással kapcsolatos kutatásokat összegezzük az idóbeli stabilitás és a faktorszerkezet tekintetében, majd összegzést végzünk a megbizhatósággal, a nemi különbségekkel és az ANPS skálák együtt járásával kapcsolatosan.

Eredmények: Az ANPS által mért konstruktumok idôben stabilak, azaz a skálák vonásokat mérnek, nem helyzetfüggó érzelmi állapotokat. A hat érzelmi rendszer két fó faktorba rendezödik (pozitív és negatív), ahol a negatív érzelmi vonások nagyobb magyarázóerốvel bírnak, mint a pozitívak. A hat (+1) skála megbizhatónak mondható (Cronbach alfa > 0,7). Az eredmények alapján a nö́k magasabb pontszámot érnek el a GONDOSKODÁS, FÉLELEM, SZOMORÚSÁG skálákon, míg a férfiak a JÁTÉKOSSÁG, KERESÉS, HARAG skálákon. A Spiritualitás skálán nincs nemi különbség. A skálák között szisztematikus együtt járások tárhatók fel.

Következtetések: Az ANPS megbizhatóan méri a személyiségünk alapjait alkotó, kéreg alatti agyterületekhez köthetố érzelmi vonásokat, gazdagítva ezzel a személyiség idegtudományi megközelitésének (Personality Neuroscience) módszertanát. Az agyi képalkotó eljárásokkal együtt alkalmazva nemcsak ezen a területen nyithat új távlatokat, hanem a klinikai pszichológiában és a kulturális összehasonlító vizsgálatok terén is.
\end{abstract}

Kulcsszavak: Jaak Panksepp, Affective Neuroscience Personality Scales (ANPS), elsödleges érzelmi rendszerek, validálás 


\section{BEVEZETÉS}

\section{Az érzelemkutatás affektív idegtudományi nézópontja}

Az affektív idegtudomány fogalmát Jaak Panksepp használta elôször (Panksepp, 1992). Röviddel ezután megjelent az elsố tanulmány (Davidson és Sutton, 1995), majd az elsố monográfia (Panksepp, 1998). A kognitív idegtudomány felôl érkezô kritikák szükségtelennek és redundánsnak tartották az „affektív idegtudomány” terminus használatát, helyette az érzelmek kognitív idegtudományi megközelítését javasolták (Lane és Nadel, 2002). Kritikájukat az idegsejtek univerzális múködésére alapozták, azaz arra, hogy az akciós potenciál kialakulásának feltételei függetlenek attól, hogy kognitív vagy affektív folyamatok során jönnek létre. Fontos megjegyezni, hogy ez a vita nem arról szólt, hogy megkérdőjelezték az affektív idegtudományi megközelítés relevanciáját vagy kétségbe vonták az érzelmek információfeldolgozásban betöltött szerepét, hanem a klasszikus érzelem-kogníció vita újjáéledésérôl van szó, és azt a folyamatot látjuk, ahogyan egy új megközelítés integrálódott a tudományos diskurzusba.

Az affektív idegtudományi megközelítés lényege és célja az, hogy feltárja az érzelmek biológiai háttérfolyamatait, leírja az emberi és az állati társas-érzelmi viselkedés sajátosságait. Többszintû elemzést alkalmaz, ezáltal integráltan kezeli a molekuláris, a neurális és a viselkedéses eredményeket, valamint egészséges és klinikai populációkat egyaránt vizsgál. Interdiszciplináris területnek tekinthetô, amely egyesíti az idegtudományi megközelítést a személyiség, az érzelmek és hangulatok pszichológiai tanulmányozásával. A kiemelkedô kutatási területek között említhetjük az érzelmek információfeldolgozási folyamatokban betöltött szerepét, az érzelmek kialakulása és szabályozása idegrendszeri alapjainak leírását (mind kérgi, mind kéreg alatti szinten), az érzelmileg telített és semleges ingerek észlelése, kódolása és felidézése közti különbségek feltárását, az érzelmi arckifejezések felismerési folyamatainak feltárását, az érzelmek döntési folyamatokra gyakorolt hatásának vizsgálatát, és az érzelmi válaszkészségben megmutatkozó egyéni különbségek és biológiai hátterük azonosítását (Armony és Vuilleumier, 2013).

Módszertanára a sokszínûség jellemzô. Klasszikus viselkedéses paradigmák (pl. érzelmi Stroop feladat, érzelmi Go/No go feladat, kondicionálás), szubjektív beszámolókon alapuló módszerek (pl. érzelmi ingerek értékelése affektív dimenziók mentén, kérdôívek), perifériás folyamatok regisztrálására szolgáló módszerek (pl. szívritmus, légzés, bôrellenállás, testhômérséklet változása, arcizmok múködése) és idegtudományi módszerek (pl. EEG, ERP, MEG, fMRI, PET) együtt adnak választ lokalizációs kérdésekre, vagy éppen funkcionális kapcsolatok és hálózatok leírása válik lehetôvé általuk.

Annak ellenére, hogy az affektív idegtudomány nem új keletú, hazai összefoglaló tanulmány eddig nem készült e témában. Részben ezt a hiányt pótoljuk jelen írásunkkal.

\section{Panksepp modellje és az ANPS kérdőiv}

Az affektív idegtudomány atyja, Jaak Panksepp a kéreg alatti érzelmi rendszerek jelentôségét hangsúlyozta. Olyan idôszakban rakta le modelljének alapjait, amikor az 
uralkodó irányvonal a kognitív idegtudományi és behaviorista szemléletnek kedvezett, nagy hangsúlyt helyezve a frontális lebenyre és végrehajtó funkciókban betöltött szerepére. Az ortodox behaviorista tanokkal szembemenve hangoztatta az érzelmek jelentôségét, ám az általa képviselt „affektív tudatosság” fogalom (Panksepp, 2005) igazán a 21. században vált a tudományos diskurzus tárgyává (Davis és Montag, 2018).

Panksepp elmélete evolúciós alapokon nyugszik (Panksepp, 1998). Kiindulópontja az a tézis, hogy kéreg alatti területek felelősek az ösztönös viselkedésért és az érzelmekért. Ezek a folyamatok valamennyi emlösben megtalálhatók, és a túlélést szolgálják. A késôbb kialakuló agykérgi területek mintegy ráépülnek ezekre az ôsi területekre. Az affektív idegtudomány ilyen tekintetben az alulról felfelé történô (bottom-up) folyamatokra helyezi a hangsúlyt, szemben a kognitív idegtudomány felülrôl lefelé ható (top-down) végrehajtó funkcióival szemben, ahol a magasabb kérgi részek szabályozzák az ôsibb területek múködését. Panksepp szerint az ôsi agyterületekhez köthetô alapvetô érzelmek jelentik a személyiségünk alapjait, hovatovább e rendszerek egyensúlytalanságával megmagyarázhatók egyes pszichopatológiai állapotok is. Sôt azáltal, hogy az alapvetô érzelmi rendszereket különbözô kulturális kontextusokban vizsgálják, megteremtôdnek a kultúrközi affektív idegtudomány alapjai (ÖzkararGradwohl, 2019).

Az affektív idegtudományi szemlélet mára a személyiség-lélektanban is meghatározóvá vált (McNaughton és Smillie, 2018). A kéreg alatti rendszerek által létrehozott érzelmeket Panksepp „elsôdleges folyamatoknak” nevezi. Ezeket úgynevezett „másodlagos folyamatok” (pl. korai tapasztalatok, tanulás) alakítják, és végleges formájukat kérgi kognitív folyamatok által érik el („harmadlagos folyamatok”) (Panksepp, 1998). Panksepp szerint a személyiség az elsôdleges érzelmekból szervezôdik alulról felfelé történô módon, következésképp a személyiségben rejlő erôforrások és gyengeségek egyaránt az affektív rendszerekben keresendôk. A kéreg alatti érzelmi rendszerek (azaz az elsôdleges folyamatok) megragadására 2003-ban kidolgozták az Affektív idegtudományi személyiség skálákat (Affective Neuroscience Personality Scales - ANPS) (Davis, Panksepp és Normansell, 2003). Az ANPS által mért elsôdleges folyamatok univerzálisnak tekinthetôk, és másodlagos folyamatok által hat rájuk a kultúra.

Az elsô, 110 tételes ANPS (Davis és mtsai, 2003) kidolgozásakor a szerzôk olyan mérốeszközt szerettek volna megalkotni, mely egyaránt hasznos az idegtudomány képviselôi és a mélylélektan követôi számára. A kérdőív hat elsôdleges érzelmi vonást mér, továbbá tartalmaz egy Spiritualitás skálát is. A hat érzelem két faktorba rendezôdik: a JÁTÉKOSSÁG, a KERESÉS és a GONDOSKODÁS skálák alkotják az Általános pozitív érzelmek csoportját, míg a FÉLELEM, a HARAG és a SZOMORÚSÁG skálákból kiszámolható az Általános negatív érzelmek mértéke.

JÁTÉKOSSÁG alatt a szerzók a humorra, szórakozásra, nevetésre és a fizikai kontaktussal együtt járó játékos helyzetekre való fogékonyságot értették, szemben a komolysággal. A KERESÉS definíciójához tartozik a kíváncsiság, a felfedezésbôl származó öröm megélése, a problémák megoldásának igénye, az új tapasztalatok elôtti pozitív várakozás érzése. A GONDOSKODÁS olyan viselkedéseket foglal magában, mint a másokkal való törôdés (kisgyermekek vagy állatok felé), a szükséget szenvedôk iránti együttérzés és empátia, továbbá a betegek ápolása. A FÉLELEM skála alá tartozik a szorongás, a feszültség, az aggodalom, döntésképtelenség, rágódás múltbéli döntése- 
ken és kijelentéseken, alvásproblémák, bátortalanság. A HARAG skála meghatározásába tartozik a forrófejûség, az ingerlékenység, a frusztráció, a frusztrációból eredó agresszió, a harag verbális és/vagy fizikai megnyilvánulása és a haragtartó viselkedés. A SZOMORÚSÁG skálához tartozik a magány érzése, a sírás gyakorisága, a szeretett személyekkel kapcsolatos gondolatok és a hiány érzése, amikor az egyén távol van a szeretteitôl. A Spiritualitás megtestesíti a magasabb rendú humán érzelmeket: az emberiséggel és a teremtett világgal való egységet, az egyed(ül)iség megélését, a belsô béke és harmónia iránti igényt és az élet értelmének keresését.

Az eredeti vizsgálatban (Davis és mtsai, 2003) a résztvevôk egyik csoportja egyetemi hallgatókból állt, a másik csoportot álláskeresốk alkották. A skálák megbízhatósága 0,65-0,86 között mozgott. A JÁTÉKOSSÁG és KERESÉS mutatkozott a leggyengébbnek (Cronbach alfa <0,7), míg a FÉLELEM, HARAG és Spiritualitás skálákon 0,8 feletti értékeket kaptak.

Mindkét csoportban nemi különbség mutatkozott az egyes skálákon. Az egyetemista csoportban a nốk magasabb pontot értek el a SZOMORÚSÁG, a GONDOSKODÁS és a Spiritualitás skálákon, mint a férfiak. A KERESÉS skálán marginális különbség mutatkozott a férfiak javára. Összevetve a két csoportot megállapítható, hogy az álláskeresôk hasonló értékeket adtak a pozitív skálákon, viszont alacsonyabb pontot értek el a negatív skálákon, mint az egyetemisták. Az álláskeresô nôk átlaga magasabb volt a GONDOSKODÁS és a SZOMORÚSÁG skálákon, mint a férfiaké. Az álláskeresố férfiak pedig a HARAG skálán mutattak fölényt a nókhöz viszonyítva.

Az ANPS skálák között számos együtt járást találtak: a JÁTÉKOSSÁG korrelált a KERESÉS és a GONDOSKODÁS skálákkal, ugyanakkor a KERESÉS és a GONDOSKODÁS nem járt együtt. A GONDOSKODÁS gyenge pozitív korrelációt mutatott a FÉLELEM és SZOMORÚSÁG skálákkal. Valamennyi negatív skála korrelált egymással, jelezvén, hogy a személyiség fölérendelt faktorát alkotják (negatív érzések). A Spiritualitás skála pozitívan korrelált a GONDOSKODÁS és KERESÉS skálákkal. Ezek az együtt járások mindkét vizsgálati csoportban megmutatkoztak.

Az ANPS módosított változata (ANPS 2.4) (Davis és Panksepp, 2011) 112 tételt tartalmaz, ezek közül 33 tétel eltér az elsố verziótól. A hat elsôdleges érzelmi skálához 14-14 tétel tartozik, a Spiritualitás skálához 12, továbbá szerepel a kérdőívben 16 töltelék tétel is (Dominancia: 7 tétel, Társas kívánatosság [hazugság skála]: 6 tétel, Szociális szorongás: 3 tétel). Valamennyi skála megbízhatósági mutatója meghaladta a 0,7-es értéket.

Összefoglalva tehát az ANPS egy érzelmi alapokon nyugvó személyiségmérô kérdôív, amellyel az idegtudományi eredmények alapján meghatározott érzelmi rendszereket mérhetjük.

\section{Célkitúzés}

Összefoglaló tanulmányunk célja egyrészt az, hogy a jelenlegi szakirodalmi hiányt pótoljuk, és megismertessük a hazai szakemberekkel nemcsak az affektív idegtudományi szemléletet, hanem rámutassunk az ebben rejlô lehetôségekre is azáltal, hogy az egyik leggyakrabban alkalmazott és egyre nagyobb tudományos népszerúségnek örvendô 
kérdôív, az Affektív idegtudományi személyiség skálák (ANPS) alkalmazási lehetôségeit sorra vesszük.

Az ANPS széles körú alkalmazási lehetôségeket kínál. Tanulmányunkban elsôként áttekintjük a kérdôív pszichometriai sajátosságait a különbözô kérdôívváltozatok öszszevetésével. Ezt követôen genetikai és neurobiológiai tanulmányok tükrében elemezzük azt a kérdést, hogy a kérdôív által mért konstruktumok milyen mértékben horgonyozhatók le biológiai folyamatokhoz?

\section{MÓDSZER}

A források felkutatásához az EBSCO Discovery Service adatbázisait használtuk. Kulcsszóként az Affective Neuroscience Personality Scales kifejezést alkalmaztuk. Elsôként kiszúrtük azokat a találatokat, amelyek több adatbázisban is megtalálhatók voltak, így a 306 találat 222-re szúkült.

Elsôdleges beválogatási kritériumnak tekintettük azt, hogy a felhasználandó tanulmány empirikus legyen, azaz olyan kutatásokat kerestünk, amelyekben adatgyújtés történt az ANPS kérdőívvel. Ebból kifolyólag kizártuk azokat a találatokat, amelyekben csupán hivatkozás történt a kérdőívre vagy annak elméleti hátterére $(n=43)$. Kizártuk továbbá az elméleti jellegú és áttekintô tanulmányokat, disszertációkat, könyveket, könyvfejezeteket, konferenciaabsztraktokat, pályázati elszámoláshoz készült kutatási beszámolókat és a személyes beszámolókat, visszaemlékezéseket ( $\mathrm{n}=27)$. A kritériumoknak megfelelt 65 empirikus tanulmány. Ezek publikálási éve 2003-2019 közé esik. Nem tekintettük kizárási kritériumnak azt, ha a publikáció nem angol nyelvú volt. A keresési folyamat egyes lépései PRISMA folyamatábrán láthatók (1. ábra) (Moher, Liberati, Tetzlaff, Altman, The PRISMA Group, 2009).

A kritériumoknak megfelelô tanulmányokat négy csoportra osztottuk: 1. validálási tanulmányok (24), 2. biológiai markerekre hivatkozó tanulmányok (13), 3. klinikai jellegú cikkek (18) és 4. egyéb, a széles körú alkalmazhatóságot igazoló publikációk (10). A források feldolgozásakor az alábbi szempontok mentén vizsgálódtunk: 1. milyen kontextusban alkalmazták az ANPS kérdôívet (pl. validálás, klinikai alkalmazás); 2. a kérdôív melyik változatát használták (pl. milyen nyelven, rövid vagy hosszú verzió, teljes kérdôív vagy egy-egy skála); 3. a résztvevốk demográfiai sajátosságai (pl. nem, életkor, nemzetiség, klinikai diagnózis); 4. a szerzôk milyen eredményrôl számolnak be. A közölt kutatási eredményekbôl négy adatot gyújtöttünk ki: a résztvevôk számát és átlagéletkorát, a hat $(+1)$ skálára adott átlagokat (nemi bontásban és/vagy összesítve), az egyes skálák megbízhatósági mutatóit és a skálák közti korrelációs együtthatókat. Terjedelmi okok miatt jelen tanulmányban csak a validálással kapcsolatos eredményeket ismertetjük, a klinikai alkalmazhatóság kérdése egy további tanulmány tárgyát képezi. 

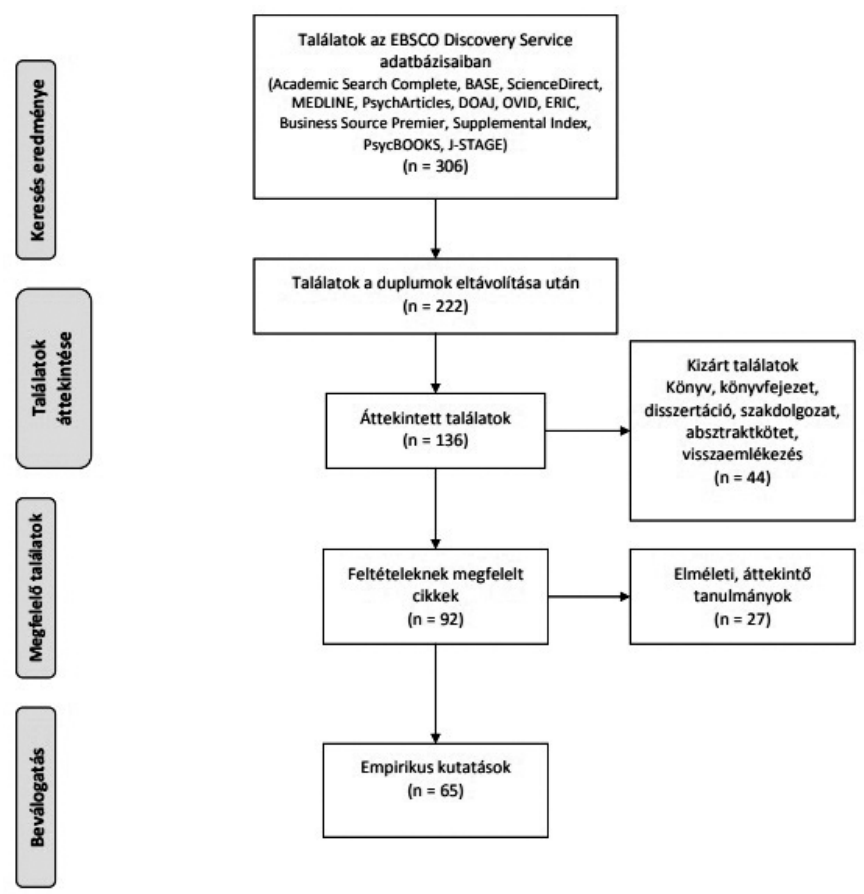

Elméleti, áttekintő tanulmányok $(n=27)$

1. ábra. PRISMA folyamatábra a szakirodalom-keresés egyes lépéseirôl

\section{EREDMÉNYEK}

A 65 empirikus tanulmányban összesítve 17889 személy vett részt, 10906 nô és 6587 férfi, 396 résztvevôrôl nincs adat. A résztvevôk átlagéletkora 28,14 év (szórás: 6,37). Többségük egyetemista vagy fiatal felnôtt.

A továbbiakban két kérdéskör mentén elemezzük a validálási kutatásokat. Elsôként kitérünk olyan pszichometriai jellemzôkre, mint az idôbeli stabilitás, faktorszerkezet, megbízhatóság, nemi különbségek és az ANPS skálák egymással való együtt járása. Terjedelmi okok miatt nem elemezzük az ANPS kérdőív kapcsolatát egyéb kérdôívekkel (pl. Big5, TCI, PANAS). Tájékoztatásul egy kiegészítô táblázatban (lsd. melléklet) felsoroljuk az ANPS kérdőívvel együtt alkalmazott egyéb mérôeszközöket. A második kérdéskör kapcsán ismertetjük azokat a konstruktumvaliditás jellegú vizsgálatokat, amelyek valamilyen biológiai markerhez kötik a skálákat.

\section{Validálás}

A validálásról szóló kutatásokban jellemzôen egyetemisták vesznek részt, viszont nagy számban találunk olyan vizsgálatokat is, amelyek valamilyen klinikai csoport eredményeit ismertetik (pl. személyiségzavar, depresszió, szerhasználat, stroke, sclerosis multiplex, vesetranszplantáción átesett betegek). 


\section{Különbözö kérdôivváltozatok kilenc nyelven}

Összesen 24 validálási tanulmányt tekintettünk át. Ezekben nagyrészt a kérdôív hoszszú változatát alkalmazták. Az ANPS hosszú változata elérhetô angol, spanyol (Abella, Panksepp, Manga, Barcena és Iglesias, 2011), francia (Pahlavan, Mouchiroud, Zenasni és Panksepp, 2008; Pingault, Pouga, Grezes és Berthoz, 2012), török (Özkarar-Gradwohl és mtsai, 2014), lengyel (Cwojdzieska és Rybakowski, 2015), olasz (Pascazio és mtsai, 2015; Giacolini és mtsai, 2017), kínai (Sindermann és mtsai, 2018) és szerb (Montag, Davis, Lazarevic és Knezevic, 2019) nyelven is.

A 112 tételes ANPS mellett létezik két rövidített kérdőív is. A francia nyelvú, 36 tételes rövid változat (ANPS-S) (Pingault, Falissard, Côté és Berthoz, 2012) elkészítésével szinte egy idôben Barrett és munkatársai (Barrett, Robins és Janata, 2013) kidolgoztak egy 33 tételes kérdôívet amerikai mintán (Brief Affective Neuroscience Personality Scales - BANPS). Ez utóbbi azonban néhány olyan új tételt is tartalmaz, amelyek az eredeti változatban nem szerepeltek. A BANPS az angol és francia mellett elérhetô perzsa (Amiri és Azad-Marzabadi, 2017) és portugál nyelven is (Gurfinkel, Mileo, Da Fonseca és Esposito, 2018). Ez utóbbi azonban inkább fordítás, mint validálás, ugyanis nagyon alacsony az elemszám $(n=30)$, az alapvetố statisztikák ismertetése pedig hiányos.

\section{Idóbeli stabilitás}

A kérdôív idôbeli stabilitásának ellenôrzése (teszt-reteszt) mind rövid, mind hosszú távon megtörtént. Két hét elteltével 0,58-0,72 közti korrelációs értékeket mértek a BANPS kérdôíven (Amiri és Azad-Marzabadi, 2017). Egy hónap elteltével, 30 fős mintán mérve 0,72-0,93 közti együtthatók jöttek ki (Pahlavan és mtsai, 2008), négy év távlatában pedig mind a hat dimenzión jó vagy kiváló $(0,67-0,78)$ mutatókat kaptak (Orri és mtsai, 2016). A megfelelô idôbeli stabilitással tehát megerôsítést nyert, hogy az ANPS vonásokat mér, nem helyzetfüggó érzelmi állapotokat.

\section{Faktorszerkezet}

Az amerikai kérdôívhez hasonlóan a török (Özkarar-Gradwohl és mtsai, 2014), az olasz (Giacolini és mtsai, 2017) és a szerb validálás (Montag és mtsai, 2019) során is megerôsítést nyert, hogy a hat elsôdleges érzelmi skála két fö faktorba rendezôdik: Negatív érzelmi vonások és Pozitív érzelmi vonások. A két faktor közül a negatív érzelmek nagyobb magyarázóerôvel bírnak, mint a pozitív érzelmek.

A szerb adatokon elvégzett faktoranalízis eredményei szerint (Montag és mtsai, 2019) a negatív érzelmek a varianciák 35,69\%-át magyarázták, míg a pozitív érzelmek 26,97\%-ot. A két faktor között gyenge negatív korrelációt találtak, ami arra utal, hogy nem független változókról van szó.

Az ANPS korábbi változatának (Davis és mtsai, 2003) olasz validálása során (Pascazio és mtsai, 2015) a hat elsôdleges érzelmi rendszer három faktorba rendezôdött a varianciák 75,18\%-át magyarázva. Az elsô faktorba tartozott a FÉLELEM, a HARAG és a SZOMORÚSÁG, a másodikba a KERESÉS és a JÁTÉKOSSÁG, míg a harmadikba a GONDOSKODÁS (pozitívan) és a HARAG (negatívan). Ez az eredmény megerôsítette a negatív érzelmek általános voltát. A pozitív érzelmek faktorát pedig egyfajta 
megközelítô viselkedéssé módosította. A harmadik faktor rámutatott az érzelmek kapcsolati természetére, melynek pozitív pólusán a mások irányába mutatott érdeklôdés és törôdés áll, a negatív póluson pedig a kapcsolat sérülése. Egy további elemzés pedig hat helyett csupán öt faktort azonosított (a KERESÉS skála volt a leggyengébb), ami további kutatások szükségességére hívta fel a figyelmet.

A korábbi tapasztalatokból okulva az ANPS 2.4 olasz validálása (Giacolini és mtsai, 2017) során nyert adatokat a szerzók két csoportra bontották. Az elsố adatsoron exploratív faktoranalízist futtattak, a második adatsoron pedig konfirmátoros faktoranalízist. Így ellenôrizték az elsố mintán feltárt faktorszerkezetet. A Spiritualitás skála figyelembevétele nélkül a két fő faktor a varianciák 47,29\%-át magyarázta nemklinikai mintán (negatív: 28,96\%, pozitív: 18,33\%). A konfirmátoros faktoranalízis elfogadható illeszkedést mutatott. A két fố faktor klinikai mintán ugyancsak nagy arányban (49,18\% ) bír magyarázóerôvel (negatív: 27,57\%, pozitív: 21,62\%).

Pahlavan és munkatársai (2008) a kérdôív faktorstruktúrájának ellenôrzésekor két modellt teszteltek: az egyik modell megfelelt a kérdőív hét skálájának, a másik modellben a két fố faktor szerepelt. Az illeszkedési mutatók alapján a hétfaktoros modell elfogadhatónak és jobbnak bizonyult a kétfaktoros modellnél. A hétfaktoros modell jobb illeszkedését a spanyol validálás során elvégzett számítások is megerôsítették a kétfaktoros struktúrával szemben (Abella és mtsai, 2011).

Annak ellenére, hogy a konfirmátoros faktoranalízis három jelentôs mutatója közül a CFI-érték nem érte el a megfelelô határértéket (CFI = 0,78; SRMR = 0,06; RMSEA = 0,039), a francia ANPS faktorstruktúrájának illeszkedését elfogadhatónak nyilvánították (Pingault, Pouga, Grezes és Berthoz, 2012).

A rövid változat (BANPS) faktorszerkezetét általában a két fö faktornak és a hat skálának megfelelóen tesztelték (Amiri és Azad-Marzabadi, 2017; Barrett és mtsai, 2013). Az iráni tanulmányban a hat skála a varianciák felét $(50,22 \%)$ magyarázta, a konfirmátoros faktoranalízis szerint pedig az illeszkedés elfogadható volt.

A 36 tételes, francia nyelvú rövidített ANPS mind a hat skálája szintén jó illeszkedési mutatókkal rendelkezik (Pingault, Falissard és mtsai, 2012). A hosszú és a rövid francia ANPS összevetése a rövid változat esetében eredményezett jobb illeszkedési mutatókat (Orri és mtsai, 2016).

Egy összehasonlító tanulmányban (Pedersen, Johansen, Wilberg és Karterud, 2014) megvizsgálták az ANPS három változatának (ANPS, BANPS, ANPS-S) pszichometriai jellemzőit 546 személyiségzavaros beteg bevonásával. Az eredmények alapján megállapítható, hogy az eredeti (hosszú) ANPS jobb belsô konzisztenciával rendelkezik, mint a két rövid változat. Ugyanakkor a hatfaktoros illeszkedés mindhárom esetben problémás volt. Legjobban a BANPS, legrosszabbul az ANPS illeszkedett a hatfaktoros elgondoláshoz. További eredmény volt, hogy túlságosan erôs korrelációt találtak a JÁTÉKOSSÁG és KERESÉS, valamint a SZOMORÚSÁG és FÉLELEM skálák között. A hosszú ANPS esetében feltáró faktorelemzéssel hét faktort azonosítottak, melyek a varianciák 40\%-át magyarázták. Ezek közül öt megfelelt az elsôdleges érzelmi rendszereknek (HARAG, JÁTÉKOSSÁG, FÉLELEM, KERESÉS, GONDOSKODÁS), a további kettô pedig ezek kombinációja volt (KERESÉS/JÁTÉKOSSÁG és SZOMORÚSÁG/ GONDOSKODÁS). 
További statisztikai elemzések alátámasztották valamennyi skála egydimenziós voltát, ami mind a hat skála esetében megkönnyíti a pontértékek interpretálhatóságát (Pingault, Falissard és mtsai, 2012).

\section{Megbízhatóság}

A megbízhatóság megállapítására született egy érdekes tanulmány (Montag és Reuter, 2008), amelyben a szerzók azt vizsgálták, hogy a kérdôívkitöltés sebessége hogyan módosítja az ANPS egyes skáláinak Cronbach-alfa-mutatóit. A 112 tételes kérdôivet papír-ceruza módszerrel kitöltôknek átlagosan 12,94 percig tartott a válaszadás. Az online kitöltéshez szükséges idô alapján hat csoportot hoztak létre. A leggyorsabbak átlagosan 5,5 perc alatt, a leglassabbak 51,79 perc alatt végeztek. A Cronbach-alfa-mutatók minden esetben meghaladták a 0,7-es értéket, azaz a kitöltés sebessége nem befolyásolta a megbízhatóságot. A közbeékelt 5 tételes hazugság skála megbízhatósága azonban negatívan korrelált a kitöltési sebességgel, azaz a lassú csoportokban magasabbak volt a Cronbach-alfa-mutatók, mint a gyors csoportokban.

Az általunk áttekintett tanulmányokban elérhető adatokon összesítô elemzést végeztünk. Elsôként kigyújtöttük a különbözô ANPS változatok Cronbach-alfa-mutatóit, majd ezekból átlagot számoltunk. Összesen 24 tanulmány 40 adatsorával dolgoztunk. Esetenként elófordult, hogy az adott tanulmányban több Cronbach-alfa-mutatót is közöltek (pl. a szerzôk több vizsgálatból álló sorozatot publikáltak egy cikken belül vagy különbözô populációkon külön-külön kiszámították a megbízhatósági mutatókat). Ezeket mi is különálló adatsorokként tekintettük. Elemzésünk alapján mind a hat érzelmi vonás skála megbízható $(0,71-0,82)$. A legalacsonyabb átlagos értékkel a KERESÉS skála rendelkezett $(0,71)$, majd a GONDOSKODÁS (0,73), SZOMORÚSÁG $(0,74)$, JÁTÉKOSSÁG $(0,77)$, HARAG $(0,8)$ és FÉLELEM $(0,82)$. A Spiritualitás skálát nem minden tanulmány elemezte, viszont az elérhetô adatok alapján ez is jónak mondható $(0,81)$.

\section{Skálák közti korreláció}

A hat $(+1)$ ANPS skála egymás közti kapcsolatát kétféle kvantitatív módszerrel elemeztük. Elsôként a tanulmányokban közölt átlagokat skálánként összegeztük, és a skálákat korreláltattuk egymással, valamint ellenôriztük a két fő faktor együtt járását. A Pozitív érzelmi vonások és Negatív érzelmi vonások fố faktorok erôs negatív korrelációja $(\mathrm{r}=-0,72)$ arra utal, hogy a kétféle érzelem nem független egymástól, hanem inkább komplementerek. Ez azt jelenti, hogy például a pozitív érzelmek túlsúlya esetén gyengébb negatív érzelmek jellemzik az egyént és fordítva. A Pozitív fö faktor a HARAG és Spiritualitás kivételével mindegyik skálával együtt járást mutat; leginkább a KERESÉS $(0,78)$ és a FÉLELEM $(-0,69)$ skálákkal. A Negatív fơ faktor is leginkább a FÉLELEM $(0,82)$ skálával függ össze, hasonlóan erôs a SZOMORÚSÁG $(0,80)$. A pozitív érzelmi rendszerek közül a KERESÉS és JÁTÉKOSSÁG közepes negatív együtt járást mutat a Negatív fớ faktorral, a GONDOSKODÁS skálával viszont tendencia jellegú gyenge negatív kapcsolat van $(-0,27, \mathrm{p}=0,76)$. Érdekes eredmény, hogy a Spiritualitás skála gyakorlatilag inverze a Negatív érzelmi fó faktornak $(r=-0,96)$. 
A pozitív érzelmi rendszerek (KERESÉS, JÁTÉKOSSÁG, GONDOSKODÁS) csoportján belül két gyenge együtt járást kaptunk: KERESÉS - JÁTÉKOSSÁG: 0,37, KERESÉS - GONDOSKODÁS: 0,3. A negatív (FÉLELEM, HARAG, SZOMORÚSÁG) csoporton belül csak a FÉLELEM és SZOMORÚSÁG korrelált $(0,63)$.

A hat skála egymás közti kapcsolatának elemzéséból látható, hogy a KERESÉS skála mindhárom negatív skálával kapcsolatban van: KERESÉS - FÉLELEM: -0,73, KERESÉS - HARAG: -0,35, KERESÉS - SZOMORÚSÁG: -0,33. A JÁTÉKOSSÁG skála közepes negatív együtt járást mutat a FÉLELEM skálával $(-0,48)$ és a SZOMORÚSÁG skálával $(-0,54)$. A GONDOSKODÁS skála pedig gyenge negatív kapcsolatban áll a SZOMORÚSÁG skálával $(-0,33)$.

A Spiritualitás két skálával mutat erôs összefüggést: a FÉLELEM skálával $(-0,91)$ és a SZOMORÚSÁG skálával $(-0,75)$. A 45 adatsorból származó elemzés eredményét az 1. táblázat mutatja.

Második elemzésünkben összerendeztük az egyes tanulmányokban közölt skálák közti korrelációs értékeket nagyságuk és gyakoriságuk alapján. A 32 adatsor összesítése a 2. táblázatban látható.

A skálák közti együtt járások összesített áttekintését ezúttal is a két fô faktoron belüli érzelmekkel kezdjük. A pozitív (KERESÉS, JÁTÉKOSSÁG, GONDOSKODÁS) csoporton belül mindhárom skála pozitív kapcsolatot mutat egymással (a korrelációs együtthatók 0,24-0,38 közé esnek), és az ANPS-tanulmányok több mint háromnegyede említést tesz ezekrôl (73-82\%). A negatív érzelmi vonások (FÉLELEM, HARAG, SZOMORÚSÁG) csoportján belül a legerôsebb kapcsolatot a FÉLELEM és SZOMORÚSÁG között találjuk $(0,60)$, a másik két esetben (HARAG-FÉLELEM, HARAG-SZOMORÚSÁG) a kapcsolat erôssége közel azonos (0,31-0,32). Ezeket az együtt járásokat szintén nagyon gyakran megtaláljuk a tanulmányokban (82-85\%-os gyakorisággal).

1. táblázat. ANPS skálák egymás közti korrelációja 45 adatsor összesítố elemzése alapján

\begin{tabular}{|c|c|c|c|c|c|c|c|c|}
\hline & 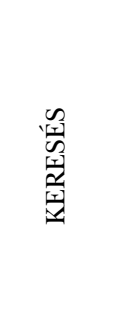 & 点 & 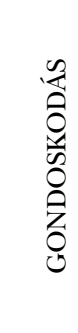 & 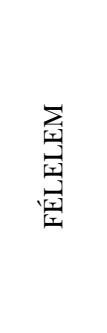 & 岁 & 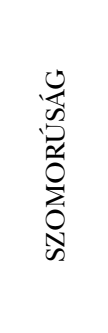 & 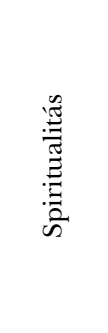 & 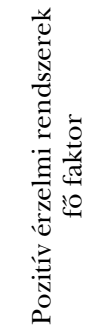 \\
\hline KERESÉS & &, $37 *$ &, $3^{*}$ &,$- 73 * * *$ &,$- 35^{*}$ &,$- 33 *$ &, 18 & $78 * * *$ \\
\hline JÁTÉK & & &,- 1 &,$- 48 * *$ &,- 22 &,$- 54 * * *$ & 07 &, $60 * * *$ \\
\hline GONDOSKODÁS & & & &,- 24 &,- 01 &,$- 33 *$ & 48 & ,64**** \\
\hline FÉLELEM & & & & &, 16 &, $63 * * *$ &,$- 91 * *$ &,$- 69 * * *$ \\
\hline HARAG & & & & & & 11 &,- 17 &,- 27 \\
\hline SZOMORÚSÁG & & & & & & &,$- 75^{*}$ &,- 59 **** \\
\hline Spiritualitás & & & & & & & &, 58 \\
\hline $\begin{array}{l}\text { Negatív érzelmi } \\
\text { rendszerek fố faktor }\end{array}$ &,$- 64 * * *$ &,$- 57 * * *$ &,- 27 &, $82 * * *$ &, $56^{* * *}$ &, $80 * * *$ &,$- 96^{* * *}$ &,$- 71 * * *$ \\
\hline
\end{tabular}

Megjegyzés: $* \mathrm{p}<, 05 ; * * \mathrm{p}<, 01 ; * * * \mathrm{p}<, 001$ 
A következókben rátérünk a pozitív és negatív skálák egymás közti kapcsolatának elemzésére. A GONDOSKODÁS skála pozitív kapcsolatban van a FÉLELEM és a SZOMORÚSÁG skálákkal, továbbá gyenge negatív kapcsolatban a HARAG skálával. Míg ez utóbbi csak ritkán bukkan fel az eredmények között (12\%), addig az elóbbiek az esetek több mint felében elôfordulnak (55-61\%). A JÁTÉKOSSÁG mindhárom negatív skálával negatív kapcsolatban van $(-0,1-0,21)$. Az elófordulási gyakoriságokat tekintve pedig hasonló a helyzet, mint a GONDOSKODÁS skálánál, azaz a FÉLELEM és SZOMORÚSÁG skálákkal való kapcsolatot gyakran (52-61\%-ban), míg a HARAG skálával való együtt járást az esetek csupán negyedében említik. A leggyengébb együtt járásokat a KERESÉS skála mutatja a három negatív érzelmi rendszerrel: a FÉLELEM és SZOMORÚSÁG skálákkal gyenge negatív $(-0,12-0,15)$, míg a HARAG skálával elhanyagolható $(0,04)$ kapcsolatot találunk. Az együtt járások gyakorisága 27-42\% között mozog.

A Spiritualitás a GONDOSKODÁS skálával van a legerôsebb kapcsolatban $(0,26)$, majd a KERESÉS, a SZOMORÚSÁG, a JÁTÉKOSSÁG, a HARAG és a FÉLELEM következik. A FÉLELEM és a HARAG kivételével valamennyi kapcsolat pozitív. A gyakoriság hasonlóan alakul: a tanulmányok szerzôi leggyakrabban a Spiritualitás és GONDOSKODÁS közti kapcsolatot említik (27\%), a legritkábban pedig a SZOMORÚSÁG skálával fordul elő $(3 \%)$.

\section{Nemi különbségek}

Az ANPS skálákon szignifikáns nemi különbségek mutatkoznak. Jellemzóen a nôk érnek el magasabb pontot a GONDOSKODÁS, a SZOMORÚSÁG és a FÉLELEM skálákon (Abella és mtsai 2011, Barrett és mtsai, 2013; Cwojdzinska és Rybakowski, 2015, Giacolini és mtsai, 2017; Pingault, Pouga és mtsai 2012; Pingault, Falissard és mtsai, 2012; Sindermann és mtsai, 2018; Orri és mtsai, 2016), míg a férfiak a JÁTÉKOSSÁG

2. táblázat. Átlósan az ANPS skálák összesített Cronbach alfa értékei. A felsố mezôben a skálák egymás közti korrelációinak átlaga 32 adatsor alapján, az alsó mezóben pedig a szakirodalomban fellelhetố elôfordulási gyakoriság százalékban kifejezve, azaz a tanulmányok milyen gyakran említik az adott skálapár szignifikáns együttjárását

\begin{tabular}{|c|c|c|c|c|c|c|c|}
\hline & 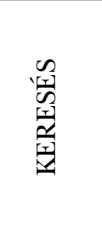 & 空 & 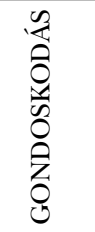 & 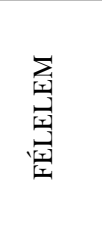 & 或 & $\begin{array}{l}0 \\
0 \\
0 \\
0 \\
0 \\
0 \\
0 \\
0 \\
0\end{array}$ & 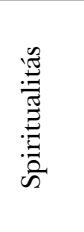 \\
\hline KERESÉS & 0,711 & ,38 & ,24 &,- 15 & 04 &,- 12 & ,20 \\
\hline JÁTÉK & $82 \%$ & 0,767 & ,36 &,- 21 &,- 10 &,- 18 & ,11 \\
\hline GONDOSKODÁS & $73 \%$ & $79 \%$ & 0,735 & , 18 &,- 13 & ,25 & ,26 \\
\hline FÉLELEM & $42 \%$ & $61 \%$ & $55 \%$ & 0,816 & ,32 & ,60 &,- 02 \\
\hline HARAG & $27 \%$ & $24 \%$ & $12 \%$ & $85 \%$ & 0,802 & ,31 &,- 03 \\
\hline SZOMORÚSÁG & $27 \%$ & $52 \%$ & $61 \%$ & $82 \%$ & $85 \%$ & 0,742 & ,19 \\
\hline Spiritualitás & $18 \%$ & $12 \%$ & $27 \%$ & $9 \%$ & $9 \%$ & $3 \%$ & 0,812 \\
\hline
\end{tabular}




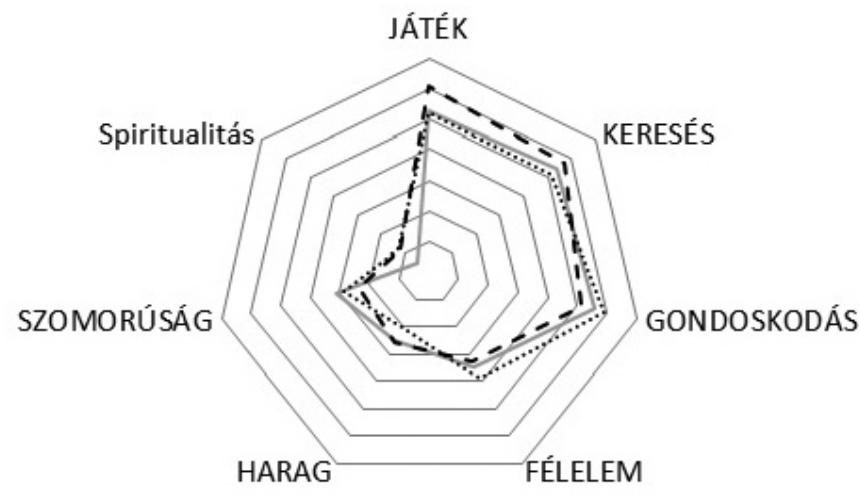

— Összesített

- - - Férfiak

Nők

2. ábra. Az ANPS egyes skáláin elért pontok összesítve és nemenként. Az összesített értékek meghatározása 20 adatsor alapján történt, a nemi bontásban ismertetett eredmények 26 adatsorból származnak

skálán (Giacolini és mtsai, 2017, Pahlavan és mtsai 2008; Pingault, Pouga és mtsai, 2012; Pingault, Fallisard és mtsai, 2012; Sindermann és mtsai, 2018).

A török validálás során a felnôtt nôk csak a GONDOSKODÁS skálán értek el magasabb pontot (Özkarar-Gradwohl és mtsai, 2014), míg a diákok csoportjában a lányok átlaga magasabb volt (a GONDOSKODÁS mellett) a JÁTÉKOSSÁG és a SZOMORÚSÁG skálákon is a fiúkhoz viszonyítva. Hasonlóképpen, a francia nôk is magasabb pontot értek el a GONDOSKODÁS és SZOMORÚSÁG skálákon, mint a francia férfiak, viszont a félelem skálán nem volt különbség (Pahlavan és mtsai, 2008). A kínai nôk csupán a SZOMORÚSÁG skálán értek el magasabb pontot, mint a kínai férfiak (Sindermann és mtsai, 2018).

A szakirodalomban hozzáférhetô adatokat összesítettük úgy, hogy z-transzformációval egységes skálát hoztunk létre. Erre azért volt szükség, mert az ANPS kérdôív különbözô változataiban eltérô pontozást használtak. A négyfokú skála egyik változatában a pontozás 0-3-ig terjed, míg a másikban 1-4-ig. A BANPS kérdőívben pedig ötfokú Likert-skálán történik a válaszadás.

Összesítésünk alapján a nôk a GONDOSKODÁS, FÉLELEM, SZOMORÚSÁG skálákon, míg a férfiak a JÁTÉKOSSÁG, KERESÉS, HARAG skálákon érnek el magasabb pontot. A Spiritualitás skálán nem mutatkozik nemi különbség.

\section{Konstruktumvaliditás vizsgálata biológiai markerekkel}

Panksepp az affektusokat a „gének hangjainak” tartotta (Watt, 2017). Ezzel a mottóval a következókben olyan kutatási eredményeket ismertetünk, amelyek az ANPS skálák által mért konstruktumok genetikai hátterét, neurokémiai alapjait, agyi strukturális és funkcionális jellegzetességeit írják le. Érintjük az öröklődés vs. környezet hatásának 
kérdését is nemcsak annak kapcsán, hogy milyen génváltozatokat sikerült azonosítani az egyes ANPS skálák által mért konstruktumok hátterében, hanem a személyiség-lélektan egy implicit módszerével, a válaszstílus-elemzéssel is. Ilyenkor azt a módot vizsgálják, ahogyan a kitöltô megadja a válaszait az önkitöltôs kérdôíveken (pl. inkább a szélsôséges válaszokat jelöli, vagy inkább elfogadja magára jellemzônek az állításokat).

Reuter és munkatársai (Reuter, Weber, Fiebach, Elger és Montag, 2009) a DARPP-32 gén személyiségre gyakorolt szerepét vizsgálták. Nemcsak a düh érzésével kapcsolatos agyi területeken mutattak ki strukturális eltéréseket, hanem genetikai bizonyítékot találtak arra vonatkozóan is, hogy a dopaminerg jelátvitel szerepet játszik a HARAG mint személyiségvonás kialakításában. Szignifikáns kapcsolatot találtak a HARAG-pontszám és a DARPP-32 gén rs907094 polimorfizmusa között. A T alléllel rendelkezô résztvevôk magasabb pontot értek el a HARAG skálán, mint a T alléllel nem rendelkezók.

Ugyancsak sikerült bizonyítani a dopaminerg rendszer és a SZOMORÚSÁG skála közti kapcsolatot (Felten, Montag, Markett, Walter és Reuter, 2011). A 9R/9R és Val/ Val genotípussal rendelkezô személyek jelentôsen alacsonyabb pontot értek el a SZOMORÚSÁG skálán, mint az eltérô génváltozattal rendelkezô társaik. A dopaminrendszer fenti génváltozata védelmet nyújthat a negatív érzelmekkel szemben, és növeli a személy ellenálló képességét a depresszióval szemben.

A szerotonerg és oxitocinerg rendszer bizonyos génváltozatai valamint a FÉLELEM és SZOMORÚSÁG skálák között interakció van (Montag, Fiebach, Kirsch és Reuter, 2011). Azok a személyek, akik rendelkeznek a szerotonin transzporter polimorfizmus homozigóta LL variánsával (5-HTTLPR LL) és az rs2268498 nukleotidpolimorfizmus TT variánsával az oxitocin receptor génen (OXTR rs2268498 TT), alacsonyabb pontot értek el a FÉLELEM és a SZOMORÚSÁG skálákon, valamint a Negatív érzelmi rendszerek fö faktoron.

Az ANPS neuroanatómiai és funkcionális alapjaival kapcsolatban azonban a kutatások kevés összefüggésre derítettek fényt. Fóként a SZOMORÚSÁG és HARAG skálák neurális alapjait sikerült azonosítani. Elsôként morfometriai kutatási eredmények mutattak ki negatív irányú összefüggést a bal amygdala szürkeállományi térfogata és a HARAG skála között (Reuter és mtsai, 2009). Késóbb pedig a nyugalomban lévô agy funkcionális konnektivitás vizsgálatával megerôsítették (Deris, Montag, Reuter, Weber és Markett, 2017), hogy a bal basolaterális amygdala és a postcentrális gyrus egy része, valamint a jobb basolaterális amygdala és a superior parietális lebeny egy része összefüggésbe hozható a SZOMORÚSÁG skálával. További ANPS skálákkal azonban nem sikerült megismételhetô eredményeket kapni.

DTI módszerrel több élvezeti szert használó (poly-drug use disorder) pácienseknél összefüggést találtak a FÉLELEM-pontszám, valamint a Superior Corona Radiata frakcionális anizotrópia (FA) értéke között (Unterrainer és mtsai, 2017). Mivel a SZOMORÚSÁG, a GONDOSKODÁS és a JÁTÉKOSSÁG skálákkal talált összefüggések tendencia jellegúek voltak $(0,05<\mathrm{p}<0,1)$, ezeket részletesen nem ismertetjük.

Egy 795 fó bevonásával végzett ikerkutatásban az ANPS skálák öröklődés és/vagy környezet általi meghatározottságát vizsgálták (Montag és mtsai, 2016). Megállapítást nyert, hogy a legalacsonyabb öröklékenység a KERESÉS rendszer esetében feltételezhetô (33\%), míg a legmagasabb a JÁTÉKOSSÁG esetében (69\%). 
Négy különbözô személyiség-kérdőív (köztük az ANPS) összesen 19 személyiségvonását fókomponens-analízissel elemezték (Savitz, Van der Merwe és Ramesar, 2008). Öt fố faktort különítettek el, amelyek a varianciák 70\%-át magyarázták. Az ANPS skálák az elsố két faktorban jelentek meg. Nem meglepô módon a FÉLELEM, a HARAG és a SZOMORÚSÁG a Negatív affektusok faktorába tartoztak (a szorongással összefüggô vonásokkal, az ártalomkerüléssel, ingerlékeny temperamentummal, az önirányítottság és kooperáció hiányával együtt). A KERESÉS, a JÁTÉKOSSÁG, a GONDOSKODÁS és a Spiritualitás pedig a Pozitív affektusok faktorába került (a transzcendenciával együtt). A genetikai meghatározottságot vizsgálva kiderült, hogy a Negatív affektusok faktoröröklékenysége 43,8\%. Az idetartozó ANPS-dimenzió a FÉLELEM, ami 26\%-ban genetikai tényezôk által determinált. A Pozitív affektusok faktor önmagában nem volt szignifikáns, viszont az idetartozó elsôdleges érzelmi rendszerek közül a KERESÉS 32,4\%-os, a GONDOSKODÁS 48,4\%-os, a Spiritualitás pedig 49,3\%-os öröklékenységet mutatott. Az SLC6A3 dopamin transzporter gén 9R allél megléte esetén csökkenti a negatív affektusokat, az SLC4A6 szerotonin transzporter gén rövid változata pedig növeli, fokozva ezzel a szorongásra és depresszióra való hajlamot. A katekol-O-metiltranszferáz (COMT) fehérjéért felelôs gén Val158Met polimorfizmus Met változata növekvô Spiritualitás-pontszámokkal mutatott összefüggést, de ezt az eredményt más kutatások nem igazolták.

Az öröklôdés vs. környezet vita másik oldalára, azaz a szocializációs folyamatok és kulturális hatások szerepére kevés példát találunk, bár esetenként a szerzôk utalnak a kulturális különbségekre (vagy azok hiányára) a validálási tanulmányokban.

Egy utánkövetéses vizsgálat ad választ arra a kérdésre, hogy a szocializáció hogyan befolyásolja az ANPS által mért konstruktumokat (Orri és mtsai, 2019). 290 triád (apa, anya, gyermek) bevonásával azt vizsgálták, hogy az anya és az apa pozitív és negatív érzelmei hogyan függnek össze az utód internalizáló és externalizáló viselkedésével. A szülôket a gyermek négyéves korában vizsgálták, a gyermek viselkedését pedig négy évvel késóbb, 8 éves korban. Az anyai és apai affektív profil eltérôen hatott a gyermek viselkedésére attól függôen, hogy milyen típusú viselkedésrôl volt szó (externalizáló vagy internalizáló), és milyen nemú volt a gyermek. Az alacsony negativitású érzelmi profil (azaz gyakoriak a pozitív érzelmek) és a magas negativitású érzelmi profil (azaz gyakoriak a negatív érzelmek) ellentétes hatást eredményezett. A durva szülôi bánásmód több externalizáló és internalizáló problémával járt együtt mind a lányoknál, mind a fiúknál. Az apai durva viselkedés az externalizáló problémákkal függött össze, az internalizáló viselkedéssel nem. Ezzel szemben az anyai durva bánásmód a lányoknál externalizáló és internalizáló problémákban egyaránt tükröződött, viszont a fiúknál sem externalizáló, sem internalizáló viselkedéssel nem járt együtt.

A tágabb szocializációs környezet, azaz a nagyvárosi létforma is befolyásolja az ANPS skálákra adott válaszokat (Sindermann és mtsai, 2017). Német és kínai résztvevôket kérdeztek meg arról, hogy milyen hosszú ideig éltek különbözô lakosságszámmal jellemezhetô településeken, mekkora lélekszámú településen születtek, és a jelenlegi lakóhelyük lakosságszámára is rákérdeztek. Ezekból az adatokból számoltak egy ún. urbanizációs mutatót. Minél nagyobb volt ez a száma, annál több idôt töltött a személy városi környezetben gyermekkorában és kamaszkorában. Az urbanizációs mutató függetlennek bizonyult az ANPS skáláktól a német résztvevók körében, a kínaiaknál 
azonban több együtt járást is felfedeztek. Például gyenge negatív kapcsolat volt az urbanizációs mutató és a FÉLELEM skála, valamint a SZOMORÚSÁG skála között a kínai nốk körében, míg a kínai férfiaknál a JÁTÉKOSSÁG pozitívan korrelált a városias létmóddal. Feltételezték, hogy ezeket az együtt járásokat az 1-5 milliós nagyvárosok sajátos életstílusa okozta, ezért megismételték az elemzést, de ezúttal kizárták a megapoliszokban felnövô és ott élô résztvevôket. Ekkor eltûntek a korrelációk, hasonlóan a német mintához.

Kérdôíves kutatásokban implicit személyiségváltozóként gyakran alkalmazzák a válaszstílust. A válaszstílus fogalma alatt sajátos válaszadási tendenciát értünk. Lehet például elfogadó (acquiescence response style - ARS), amikor a kitöltố jellemzôen „egyetértek” vagy „nagyon egyetértek” válaszokat ad. Beszélhetünk továbbá szélsôséges válaszstílusról (extreme response style - ERS), amikor a kitöltô elônyben részesíti a skála végpontjain lévô válaszlehetôségeket, például „nagyon jellemzô” vagy „egyáltalán nem jellemző”. Egy kutatásban az ANPS skálákat alkalmazták explicit személyiségjellemzők feltárására, és összevetették a válaszstílussal mint implicit személyiségjellemzôvel. Az ANPS skálák és a válaszstílus közti korreláció meglehetôsen alacsony volt. A szélsôséges válaszstílus a KERESÉS, GONDOSKODÁS, JÁTÉKOSSÁG skálákkal pozitívan, a Spiritualitás skálával negatívan korrelált. Az elfogadó válaszstílus pedig pozitív együtt járást mutatott a KERESÉS, a GONDOSKODÁS, a SZOMORÚSÁG és a Spiritualitás skálákkal. Az elfogadó válaszstílus 37\%-ban örökletesnek bizonyult, míg a szélsôséges válaszstílus 57\%-ban (Melchers és mtsai, 2018). Ez utóbbi összefüggésben áll a szerotonin transzporter gén 5-HTTLPR variánsával is (Plieger, Montag, Felten és Reuter, 2014).

A Spiritualitás skála validálásaként értelmezhetô az a kutatás, amelyben a spirituális élmény változását vizsgálták LSD hatására (Preller és mtsai, 2017). A résztvevoók különbözô zenéket hallgattak, és el kellett dönteniük, hogy a zenének van-e személyes jelentése (relevanciája) vagy semleges számukra? $200 \mathrm{mg}$ LSD hatására a spirituális élmény nem változott, legalábbis az ANPS Spiritualitás skála tükrében nem. A szerzôk azzal magyarázzák az eredményt, hogy egyrészt a résztvevôk Spiritualitás pontszáma jóval alacsonyabb volt, mint a normatív standardértékek, másrészt az MRI-vizsgálati helyzet (pl. szûk tér, erôs zaj) nem kedvez a spirituális élmények megjelenésének. Bár az ANPS Spiritualitás skála pontszám nem játszott kitüntetett szerepet (a kísérlet során nem változott), a szerzók kimutatták az 5-HT2A receptor szerepét és egyes agyi területek jelentôségét az LSD indukálta jelentéstulajdonítási folyamatokban.

A kreativitás pszichológiai és biológiai markereinek feltárásakor kiderült, hogy az ANPS KERESÉS skálája pozitívan korrelál a nyálból vett tesztoszteronnal (Reuter és mtsai, 2005). Más kutatások (Van der Westhuisen és Solms, 2015) azonban negatív kapcsolatot találtak a tesztoszteron és a KERESÉS között. Ugyancsak negatív kapcsolat mutatkozott a tesztoszteron és a HARAG között is. Továbbá a JÁTÉKOSSÁG negatívan korrelált a kortizollal. 


\section{MEGVITATÁS}

Áttekintố tanulmányunk a személyiségvonások érzelmi alapjairól szól affektív idegtudományi megközelítésben. Elsôsorban módszertani szempontokra helyeztük a hangsúlyt, és az Affektív idegtudományi személyiség skálák (Affective Neuroscience Personality Scales - ANPS) alkalmazásán keresztül összegeztünk 24 validálási és 13 biológiai tanulmányt.

Tanulmányunk elsôdleges célja a hazai affektív idegtudományi szakirodalom bốvítése, betöltve az áttekintố tanulmány hiányából fakadó hézagot, másodlagos cél pedig a folyamatban lévố magyar ANPS validálás elókészítése.

Jelen tanulmány erôsségei között említhetố az, hogy empirikus tanulmányok elemzésén alapul, és naprakész publikációkra épít. Számos korlátot meg kell azonban említeni. Elsốként azt, hogy terjedelmi okok miatt szétválasztottuk a validálási és a klinikai jellegú tanulmányokat, így az ANPS klinikai alkalmazhatósága kimaradt. Továbbá, az áttekintéshez felhasznált írások minősége nagyon változó volt, esetenként hiányoztak fontos pszichometriai mutatók vagy statisztikai elemzések. Végül fontos megemlíteni, hogy tanulmányunk bôvíthetố egyéb szakirodalmi forrásokkal (pl. doktori értekezések, könyvfejezetek), amelyeket már a források felkutatásának fázisában kizártunk.

A 65 empirikus tanulmányt kvantitatív elemzésnek vetettük alá, továbbá számításokat végeztünk a megbízhatóság, a skálák közti kapcsolatok és a nemi különbségek tekintetében. Az elemzések egyik legfontosabb eredménye az, hogy az ANPS kérdôiv megbízható mérốszköze az elsôdleges érzelmi rendszereknek, hiszen a skálák összesített megbízhatósági értéke minden skála esetében meghaladja a 0,7-es értéket. Bár nem diagnosztikai eszköz, a klinikai mintán elvégzett validálási vizsgálatok (Giacolini és mtsai, 2017; Pascazio és mtsai, 2010; Pedersen és mtsai, 2014) arra utalnak, hogy az ANPS alkalmas egyes betegcsoportok elkülönítésére (az egészséges kontrollcsoporttól), továbbá képes elôrejelezni egyes viselkedésmódokat (pl. kreativitás, kérdốvkitöltési válaszstílus, agresszió).

Alátámasztást nyert a kvantitatív elemzés során, hogy amennyiben a hat érzelmi rendszert két csoportba soroljuk (pozitív érzelmi rendszerek: KERESÉS, JÁTÉKOSSÁG, GONDOSKODÁS és negatív érzelmi rendszerek: FÉLELEM, HARAG, SZOMORÚSÁG), és megvizsgáljuk a viszonyukat, akkor a negatív és pozitív fố faktor egymástól nem függetlenként, hanem komplementerekként jelennek meg. Ez a két fó érzelmi rendszer nyújthat alapot a tanulás (jutalmazás és büntetés) által formálódó további érzelmekhez. Kiegészítésként mérhetố a Spiritualitás.

Az ANPS által mért konstruktumok idôben stabilak, azaz a skálák vonásokat mérnek, nem helyzetfüggó érzelmi állapotokat. A negatív érzelmi vonások nagyobb hangsúllyal szerepelnek: a varianciákat nagyobb százalékban magyarázzák, mint a pozitív érzelmek. Az a tény, hogy a faktorszerkezet változatos attól függóen, hogy melyik validálási tanulmányról van szó és melyik kérdôívváltozattal dolgoztak, további kutatások szükségességére hívja fel a figyelmet, hiszen két-, három-, öt-, hat- és hétfaktoros modellek is születtek változatos eredménnyel. Mi lehet ennek az oka? Úgy gondoljuk, hogy a kétfaktoros elgondolások mögött egy, az érzelmi jelenségekre általában jellemzố univerzális sajátosság áll. Ez a valencia, azaz a kellemes-kellemetlen (pozitívnegatív) dimenzión történố elhelyezés. Ez a fajta érzelmi különbségtevés („érzelmi 
tudás”) egyszerú és gyors tájékozódást tesz lehetôvé az egyén számára. Az érzelmekben való jártasság egy ennél specifikusabb és differenciáltabb szintjét jelzik a három-, öt-, hat-, hétfaktoros modellek, ahol az „érzelmi tudás” egyrészt biológiai alapokon nyugvó rendszerek mentén szervezódik, másrészt beágyazódik egy kulturális közegbe, ahol szocializációs folyamatok által fejlődik, alakul. Az ANPS faktorszerkezetére vonatkozó változatos modellek jelezhetik az érzelmek kulturális változékonyságát.

A skálák közti szisztematikus együtt járások rámutatnak az érzelmi rendszerek szervezôdésére. A negatív érzelmek (pl. SZOMORÚSÁG, FÉLELEM) beindíthatják a megközelítố viselkedést (KERESÉS, GONDOSKODÁS), ezáltal érzelemszabályozási mechanizmusokat élesítenek és/vagy mobilizálják a szociális kapcsolatokat. A negatív skálák egymás közti együtt járása nagyon gyakori (a tanulmányok több mint 80\%-ában ismertetik). Míg a FÉLELEM és SZOMORÚSÁG a legerôsebben kapcsolódó érzelmi rendszerek, addig a HARAG független tôlük, és más skálákkal is gyengén korrelál. A FÉLELEM és SZOMORÚSÁG erôs kapcsolata utalhat egyrészt arra, hogy fölérendelt negatív érzelmi kategóriát alkotnak, másrészt a hasonló neurális háttérfolyamatok miatt nehezen elkülöníthetôk (Davis és mtsai, 2003). Harmadrészt, rámutat az interperszonális kapcsolatok dinamikájára, hiszen egy szeretett személy elvesztésének félelme, a szeparáció gondolata szomorúságot indukál. Hasonlóan a negatív skálákhoz, a pozitív skálák szintén gyakran korrelálnak egymással, a kapcsolat erôssége azonban gyenge (0,4 alatti). Ez arra utal, hogy kevésbé függnek egymástól ezek az érzelmi rendszerek. A negatív és pozitív érzelmi vonások negatív együtt járása pedig azzal magyarázható, hogy a negatív érzések kedvezôtlenül hatnak a nyitottságot, explorációt, kreativitást feltételezố viselkedésmódokra.

Az egyes skálákon megmutatkozó, több kultúrában is megjelenó nemi különbségek az érzelmi vonások univerzális jellegét tükrözik. A nôk GONDOSKODÁS skálán elért magasabb pontja az utódokkal való törôdéssel és a kötôdéssel mint genetikailag előhuzalozott, evolúciós örökséggel magyarázható (Giacolini és mtsai, 2017; ÖzkararGradwohl és mtsai, 2014). A nôk negatív skálákon elért magasabb pontszáma ugyancsak összhangban van más személyiségmérô skálák eredményeivel (pl. erôsebb szorongás, érzelmi labilitás) (Davis és mtsai, 2003).

A hat érzelemre olyan vonásokként tekintünk, amelyek biológiai beágyazottsággal bírnak, és a személyiségünk alapköveit alkotják. Különösen erôs genetikai meghatározottsággal bírnak a negatív érzelmek (Felten és mtsai 2011; Montag és mtsai, 2011; Savitz és mtsai, 2008).

\section{KONKLÚZIÓ}

Az ANPS kérdőív megbízható mérôeszköze az elsôdleges érzelmi rendszereknek. A két fő faktor (pozitív és negatív) mellett három-három alapvetô, vonás jellegú érzelmi rendszer mérésére alkalmas, amelyek mindegyike megfelelô pszichometriai mutatókkal rendelkezik. A skálák között szisztematikus együtt járások találhatók, és jellegzetes nemi különbségek vannak az egyes skálákon (pl. nốk magasabb pontja a negatív skálákon). A fentiek alapján az ANPS jó szívvel ajánlható kutatási célokra, ugyanakkor tekintetbe kell venni, hogy az eredeti ANPS kitöltése eléggé idôigényes. Mindazonál- 
tal megfelelố eszköz egy új, formálódó irányvonal a személyiség idegtudományi megközelítésének (Personality Neuroscience) módszertanában, ami az agyi képalkotó eljárásokkal együtt alkalmazva nemcsak ezen a területen nyithat új távlatokat, hanem a klinikai pszichológiában és a kulturális összehasonlító vizsgálatok terén is.

\section{KÖSZÖNETNYILVÁNÍTÁS}

A tanulmány a PD124964 számú projekt keretében készült a Nemzeti Kutatási Fejlesztési és Innovációs Alapból biztosított támogatással, a posztdoktori kiválósági program finanszírozásában. Köszönetünket fejezzük ki továbbá Massimiliano Orrinak és Goran Kneževićnek a kanadai és szerb ANPS adatokhoz való hozzáférésben nyújtott nagylelkú segítségükért.

\section{IRODALOM}

Abella, V., Panksepp, J., Manga, D., Bárcena, C., \& Iglesias, J. A. (2011). Spanish validation of the affective neuroscience personality scales. The Spanish Journal of Psychology, 14(2), 926-935.

Amiri, S., \& Azad-Marzabadi, E. (2017). Validation of Affective Neuroscience Personality Scales in normal populations. Neuropsychiatria $i$ Neuropsychologia/Neuropsychiatry and Neuropsychology, 12(3), 95-100.

Armony, J., \& Vuilleumier, P. (Eds) (2013). The Cambridge handbook of human affective neuroscience. Cambridge University Press.

Barrett, F. S., Robins, R. W., \& Janata, P. (2013). A brief form of the Affective Neuroscience Personality Scales. Psychological Assessment, 25(3), 826.

Cwojdzieska, A., \& Rybakowski, F. (2015). Operacjonalizacja koncepcji mózgowych systemów emocjonalnych Jaaka Pankseppa-Affective Neuroscience Personality Scales (Neuroafektywne skale osobowo[ci). Neuropsychiatry and Neuropsychology/Neuropsychiatria $i$ Neuropsychologia, 10(3-4), 102-109.

Davidson, R. J., \& Sutton, S. K. (1995). Affective neuroscience: The emergence of a discipline. Current Opinion in Neurobiology, 5(2), 217-224.

Davis, K. L., \& Panksepp, J. (2011). The brain's emotional foundations of human personality and the Affective Neuroscience Personality Scales. Neuroscience és Biobehavioral Reviews, 35(9), $1946-1958$.

Davis, K. L., Panksepp, J., \& Normansell, L. (2003). The affective neuroscience personality scales: Normative data and implications. Neuropsychoanalysis, 5(1), 57-69.

Davis, K. L., \& Montag, C. (2018). A tribute to Jaak Panksepp (1943-2017). Personality Neuroscience, $1(\mathrm{e} 9), 1-4$.

Deris, N., Montag, C., Reuter, M., Weber, B., \& Markett, S. (2017). Functional connectivity in the resting brain as biological correlate of the Affective Neuroscience Personality Scales. NeuroImage, 147, 423-431.

Felten, A., Montag, C., Markett, S., Walter, N. T., \& Reuter, M. (2011). Genetically determined dopamine availability predicts disposition for depression. Brain and Behavior, 1(2), 109-118.

Gazzillo, F., Gorman, B., De Luca, E., Faccini, F., Bush, M., Silberschatz, G., \& Dazzi, N. (2018). Preliminary Data about the Validation of a Self-Report for the Assessment of Interpersonal Guilt: The Interpersonal Guilt Rating Scales-15s (IGRS-15s). Psychodynamic Psychiatry, 46(1), 23-48. 
Giacolini, T., Ardizzone, I., Davis, K. L., Ferrara, M., Picconi, L., Terrinoni, A., \& Sabatello, U. (2017). Brain emotional systems: The Italian version of the ANPS-Affective Neuroscience Personality Scales 2.4 (reliability and validity). Clinical Neuropsychiatry, 14(4), 263-274.

Gurfinkel, Y., Mileo, R. A., Da Fonseca, M. S. M., \& Esposito, S. B. (2018). Tradução para o português e adaptação transcultural da Affective Neuroscience Personality Scales-Brief. Revista da Faculdade de Ciências Médicas de Sorocaba, 20(4), 223-229.

Hiebler-Ragger, M., Fuchshuber, J., Dröscher, H., Vajda, C., Fink, A., \& Unterrainer, H. F. (2018). Personality influences the relationship between primary emotions and religious/ spiritual well-being. Frontiers in Psychology, 9, 370.

Knežević, G., Lazarević, L. B., Montag, C., \& Davis, K. (2019). Relations Between Lexical and Biological Perspectives on Personality: New Evidence Based on HEXACO and Affective Neuroscience Theory. Journal of Personality Assessment, 102(3), 1-12.

Lane, R. D., \& Nadel, L. (Eds) (2002). Cognitive neuroscience of emotion. Oxford University Press.

McNaughton, N., \& Smillie, L. D. (2018). Some metatheoretical principles for personality neuroscience. Personality Neuroscience, 1(e11), 1-13.

Melchers, M., Plieger, T., Montag, C., Reuter, M., Spinath, F. M., \& Hahn, E. (2018). The heritability of response styles and its impact on heritability estimates of personality: A twin study. Personality and Individual Differences, 134, 16-24.

Moher D., Liberati A., Tetzlaff J., Altman D. G., \& The PRISMA Group (2009). Preferred Reporting Items for Systematic Reviews and Meta-Analyses: The PRISMA Statement. PLoS Medicine, 6(7), e1000097

Montag, C., Davis, K. L., Lazarevic, L. B., \& Knezevic, G. (2019). A Serbian version of the ANPS and its link to the five-factor model of personality. Open Psychology, 1(1), 303-316.

Montag, C., Fiebach, C. J., Kirsch, P., \& Reuter, M. (2011). Interaction of 5-HTTLPR and a variation on the oxytocin receptor gene influences negative emotionality. Biological Psychiatry, 69(6), 601-603.

Montag, C., Hahn, E., Reuter, M., Spinath, F. M., Davis, K., \& Panksepp, J. (2016). The role of nature and nurture for individual differences in primary emotional systems: evidence from a twin study. PLoS One, 11(3), e0151405.

Montag, C., \& Reuter, M. (2008). Does speed in completing an online questionnaire have an influence on its reliability? CyberPsychology and Behavior, 11(6), 719-721.

Orri, M., Rouquette, A., Pingault, J. B., Barry, C., Herba, C., Cote, S. M., \& Berthoz, S. (2016). Longitudinal and sex measurement invariance of the affective neuroscience personality scales. Assessment, 25(5), 653-666.

Orri, M., Pingault, J. B., Rouquette, A., Lalanne, C., Falissard, B., Herba, C., et al. (2017). Identifying affective personality profiles: a latent profile analysis of the affective neuroscience personality scales. Scientific Reports, 7(1), 1-14.

Orri, M., Girard, L. C., Pingault, J. B., Rouquette, A., Herba, C., Falissard, B., et al. (2019). Harsh parenting practices mediate the association between parent affective profiles and child adjustment outcomes: Differential associations for mothers and fathers. International Journal of Behavioral Development, 43(1), 53-60.

Özkarar-Gradwohl, F. G., Panksepp, J., İçöz, F. J., Çetinkaya, H., Köksal, F., Davis, K. L., \& Scherler, N. (2014). The influence of culture on basic affective systems: the comparison of Turkish and American norms on the affective neuroscience personality scales. Culture and Brain, 2(2), 173-192.

Özkarar-Gradwohl, F. G. (2019). Cross-Cultural Affective Neuroscience. Frontiers in Psychology, 10,794 . 
Pahlavan, F., Mouchiroud, C., Zenasni, F., \& Panksepp, J. (2008). Validation de l'adaptation française de l'échelle neuro-affective de personnalité. European Review of Applied Psychology, 58(3), 155-163.

Panksepp, J. (1992). A critical role for „affective neuroscience” in resolving what is basic about basic emotions. Psychological Review, 99(3), 554-560.

Panksepp, J. (1998). Affective Neuroscience: The Foundations of Human and Animal Emotions. New York: Oxford University Press.

Panksepp, J. (2005). Affective consciousness: Core emotional feelings in animals and humans. Consciousness and Cognition, 14(1), 30-80.

Pascazio, L., Nardone, I. B., Clarici, A., Enzmann, G., Grignetti, M., Panzetta, G. O., \& Vecchiet, C. (2010). Anxiety, depression and emotional profile in renal transplant recipients and healthy subjects: a comparative study. Transplantation Proceedings, 42(9), 3586-3590.

Pascazio, L., Bembich, S., Nardone, I. B., Vecchiet, C., Guarino, G., \& Clarici, A. (2015). Validation of the Italian translation of the affective neuroscience personality scales. Psychological Reports, 116(1), 97-115.

Pedersen, G., Johansen, M. S., Wilberg, T., \& Karterud, S. (2014). Testing different versions of the affective neuroscience personality scales in a clinical sample. PloS One, 9(10), e109394.

Pingault, J. B., Falissard, B., Côté, S., \& Berthoz, S. (2012). A new approach of personality and psychiatric disorders: a short version of the Affective Neuroscience Personality Scales. PloS One, 7(7), e41489.

Pingault, J. B., Pouga, L., Grezes, J., \& Berthoz, S. (2012). Determination of emotional endophenotypes: A validation of the Affective Neuroscience Personality Scales and further perspectives. Psychological Assessment, 24(2), 375-385.

Plieger, T., Montag, C., Felten, A., \& Reuter, M. (2014). The serotonin transporter polymorphism (5-HTTLPR) and personality: response style as a new endophenotype for anxiety. International Journal of Neuropsychopharmacology, 17(6), 851-858.

Preller, K. H., Herdener, M., Pokorny, T., Planzer, A., Kraehenmann, R., Stämpfli, P., et al (2017). The fabric of meaning and subjective effects in LSD-induced states depend on serotonin 2A receptor activation. Current Biology, 27(3), 451-457.

Reuter, M., Panksepp, J., Schnabel, N., Kellerhoff, N., Kempel, P., \& Hennig, J. (2005). Personality and biological markers of creativity. European Journal of Personality: Published for the European Association of Personality Psychology, 19(2), 83-95.

Reuter, M., Weber, B., Fiebach, C. J., Elger, C., \& Montag, C. (2009). The biological basis of anger: associations with the gene coding for DARPP-32 (PPP1R1B) and with amygdala volume. Behavioural Brain Research, 202(2), 179-183.

Savitz, J., Van der Merwe, L., \& Ramesar, R. (2008). Personality endophenotypes for bipolar affective disorder: a family-based genetic association analysis. Genes, Brain and Behavior, 7(8), 869-876.

Sawaya, H., Johnson, K., Schmidt, M., Arana, A., Chahine, G., Atoui, M., et al. (2015). Resting-state functional connectivity of antero-medial prefrontal cortex sub-regions in major depression and relationship to emotional intelligence. International Journal of Neuropsychopharmacology, 18(6), pyu112.

Schriber, R. A., Chung, J. M., Sorensen, K. S., \& Robins, R. W. (2017). Dispositional contempt: A first look at the contemptuous person. Journal of Personality and Social Psychology, 113(2), 280-309.

Sindermann, C., Kendrick, K. M., Becker, B., Li, M., Li, S., \& Montag, C. (2017). Does growing up in urban compared to rural areas shape primary emotional traits? Behavioral Sciences, $7(3), 60$. 
Sindermann, C., Luo, R., Zhao, Z., Li, Q., Li, M., Kendrick, K. M., et al (2018). High ANGER and low agreeableness predict vengefulness in German and Chinese participants. Personality and Individual Differences, 121, 184-192.

Unterrainer, H. F., Hiebler-Ragger, M., Koschutnig, K., Fuchshuber, J., Tscheschner, S., Url, M., et al (2017). Addiction as an attachment disorder: white matter impairment is linked to increased negative affective states in poly-drug use. Frontiers in Human Neuroscience, 11, 208.

Van der Westhuizen, D., \& Solms, M. (2015). Social dominance and the affective neuroscience personality scales. Consciousness and Cognition, 33, 90-111.

Watt, D. F. (2017). Reflections on the neuroscientific legacy of Jaak Panksepp (1943-2017). Neuropsychoanalysis, 19(2), 183-198.

\title{
MEASURING PRIMARY EMOTIONS FROM AN AFFECTIVE NEUROSCIENCE PERSPECTIVE: METHODOLOGICAL REVIEW
}

\author{
DEÁK, ANITA
}

Introduction: In this review we focus on emotional basics of personality traits from affective neuroscience perspective. We summarize empirical studies using the Affective Neuroscience Personality Scales (ANPS) that was developed for measuring six $(+1)$ primary emotional systems located in subcortical brain areas (FEAR, ANGER, SADNESS, PLAYFULNESS, SEEK, CARE, Spirituality).

Methods: We selected 65 empirical studies published between 2003 and 2019 where ANPS questionnaire was used. We divided the studies into four clusters: validation studies, studies with biological markers, clinical studies and others demonstrating different application of the ANPS. In this review we summarized the validation studies in regard to the test-retest reliability, factor structure of the ANPS, then we conducted statistical analysis on 39 datasets for reliability, on 25 datasets for sex differences and inter-scale correlations (33 and 45 datasets).

Results: Based on the test-retest analysis ANPS constructs measure emotional traits, not context-dependent affects. The six primary emotions form two main factors (positive and negative emotions), and the negative emotions have greater explanation power than positive emotions. The six $(+1)$ scales are reliable $($ Cronbach alphas > 0,7). Results show that women have higher scores on CARE, FEAR and SADNESS, while men's scores are higher on PLAYFULNESS, SEEK and ANGER. No sex difference appeared on Spirituality scale. However, systematic inter-scale correlations were found.

Conclusions: The ANPS questionnaire is a valid and reliable tool for measuring primary emotions that are located in the subcortical brain areas and are the building blocks of personality traits. It is a self-report measure of the recently developing field of personality neuroscience. As a self-report instrument of brain imaging studies it can open new perspectives not only in neuroscience, but in clinical psychology and in cross-cultural studies.

Keywords: Jaak Panksepp, Affective Neuroscience Personality Scales (ANPS), primary emotional systems, validation

A cikk a Creative Commons Attribution 4.0 International License (https://creativecommons. org/licenses/by/4.0) feltételei szerint publikált Open Access közlemény, melynek szellemében a cikk bármilyen médiumban szabadon felhasználható, megosztható és újraközölhetô, feltéve, hogy az eredeti szerzó és a közlés helye, illetve a CC License linkje és az esetlegesen végrehajtott módosítások feltüntetésre kerülnek. (SID_1) 
MELLÉKLET

\begin{tabular}{|c|c|c|c|c|c|c|c|c|}
\hline 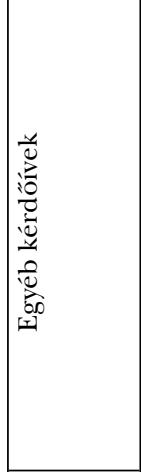 & 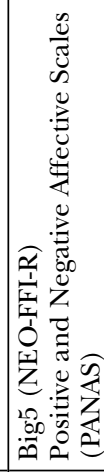 & 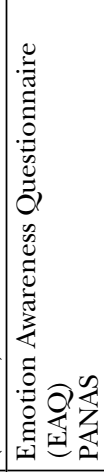 & 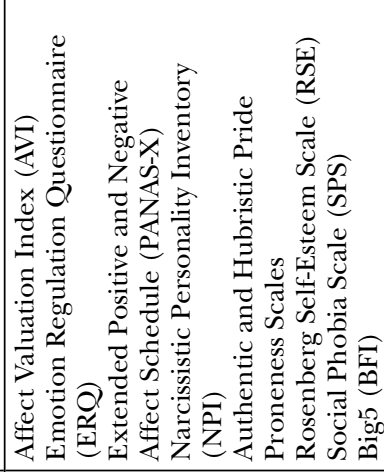 & 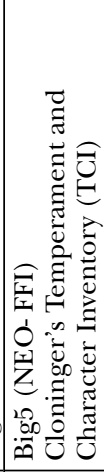 & & 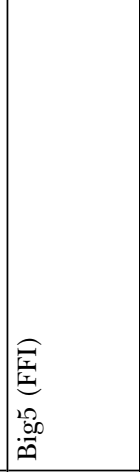 & & \\
\hline 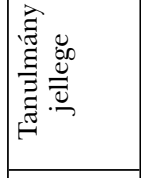 & 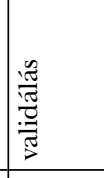 & 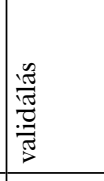 & 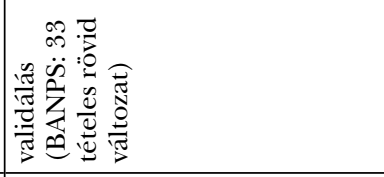 & 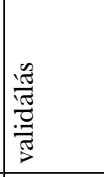 & 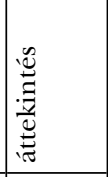 & 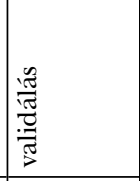 & 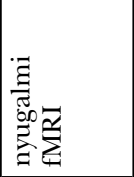 & 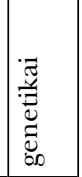 \\
\hline 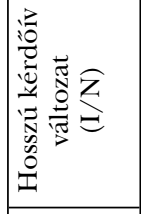 & 工 & $z$ & $\begin{array}{l}\infty \\
\vdots \\
\vdots \\
\infty \\
0 \\
\pm \\
-\end{array}$ & - & 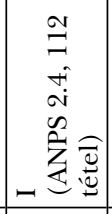 & 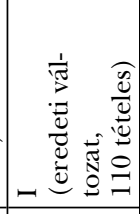 & - & - \\
\hline$\frac{z}{0}$ & 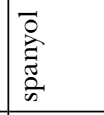 & 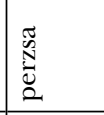 & $\begin{array}{l}\overline{0} \\
\dot{0} \\
\tilde{c} \\
\tilde{\sigma}\end{array}$ & 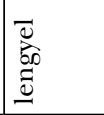 & \begin{tabular}{|l}
$\overrightarrow{0}$ \\
品 \\
$\tilde{\sigma}$
\end{tabular} & 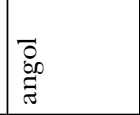 & 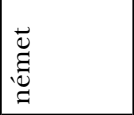 & 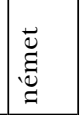 \\
\hline 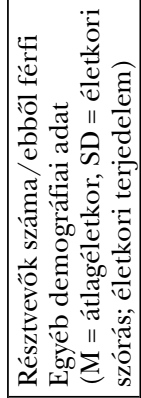 & 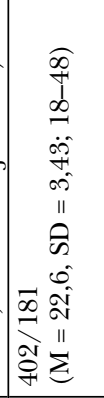 & 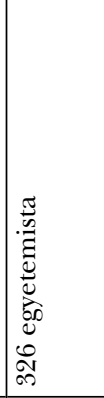 & 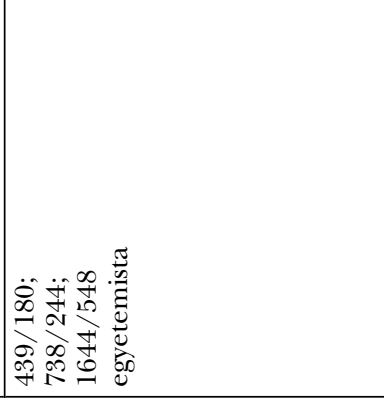 & 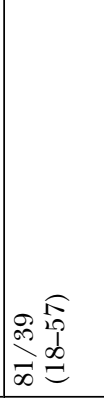 & 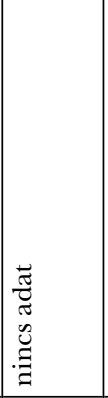 & 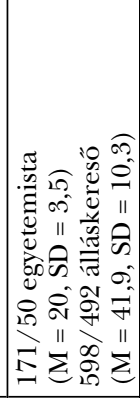 & 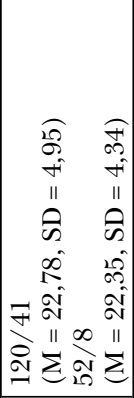 & 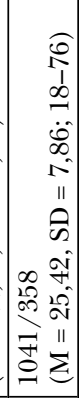 \\
\hline 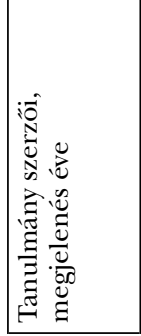 & 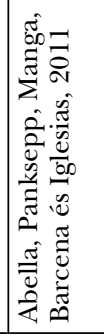 & 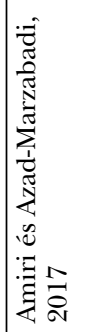 & 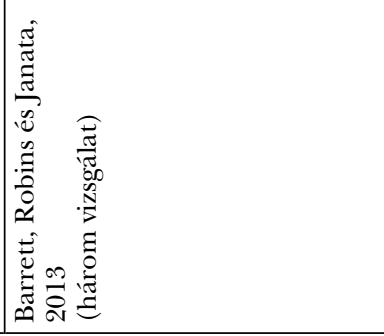 & 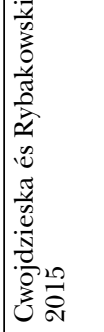 & 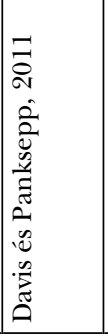 & 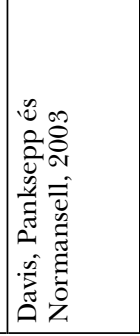 & 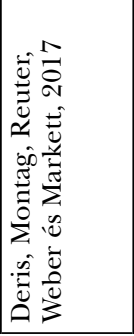 & 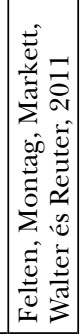 \\
\hline
\end{tabular}




\begin{tabular}{|c|c|c|c|c|c|c|c|c|}
\hline 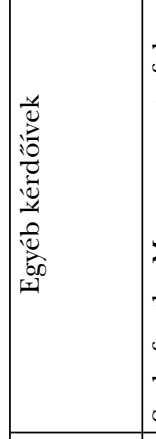 & 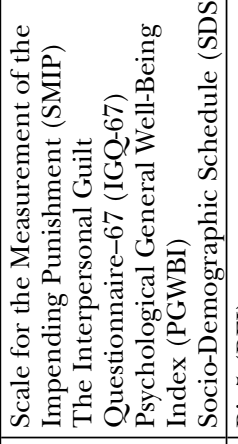 & & & 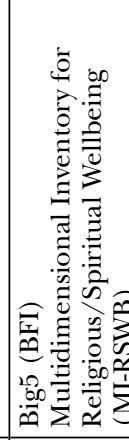 & 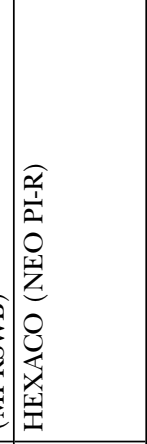 & & & 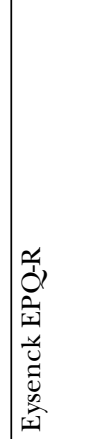 \\
\hline 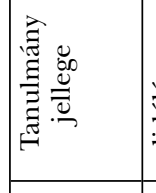 & 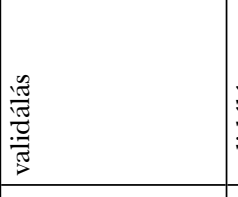 & 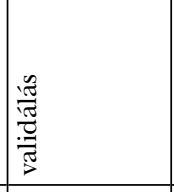 & 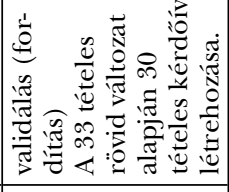 & | & 尌 & | & 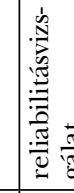 & 这 \\
\hline 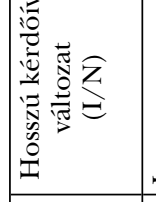 & - & - & $z$ & - & - & - & - & 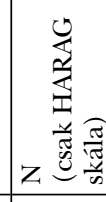 \\
\hline & $\frac{\frac{y}{0}}{0}$ & $\begin{array}{l}\frac{2}{0} \\
\frac{8}{0}\end{array}$ & 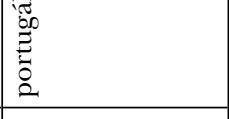 & 苞 & 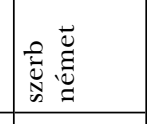 & 产 & | & 苛 \\
\hline 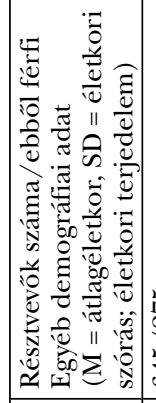 & 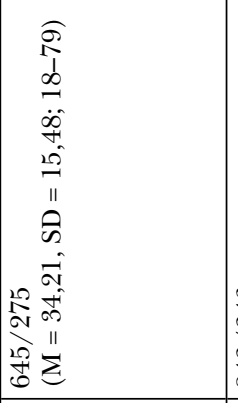 & 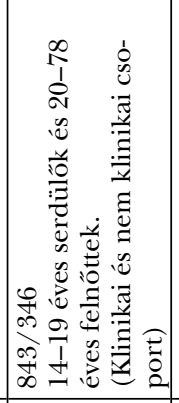 & 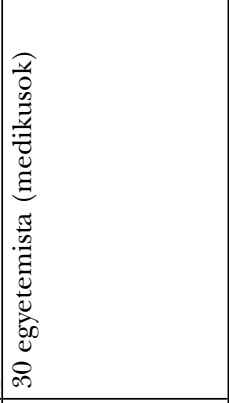 & 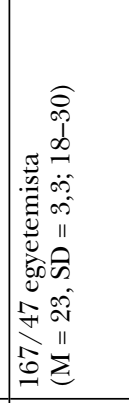 & 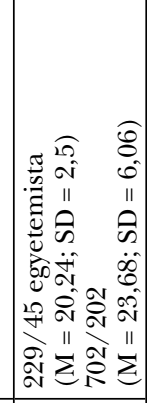 & 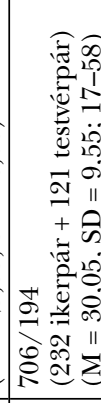 & 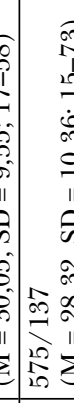 & 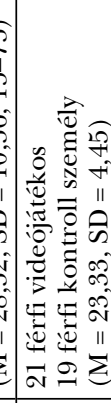 \\
\hline 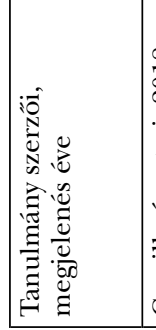 & 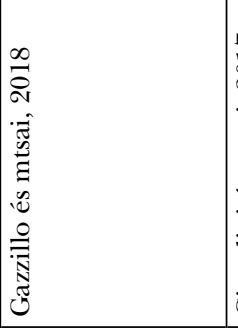 & 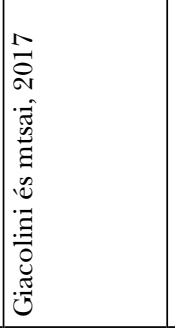 & 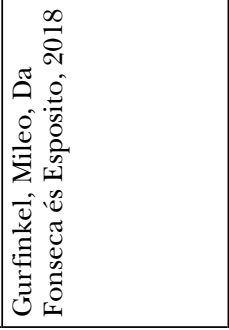 & 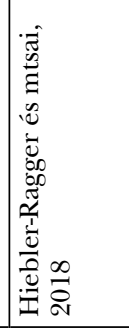 & 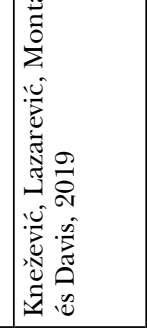 & 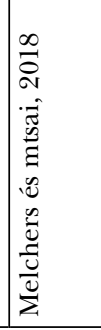 & 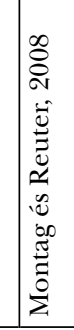 & 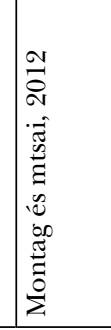 \\
\hline
\end{tabular}




\begin{tabular}{|c|c|c|c|c|c|c|c|c|}
\hline 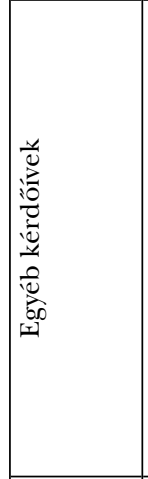 & & 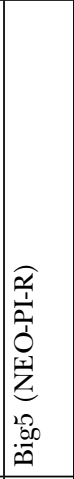 & & & 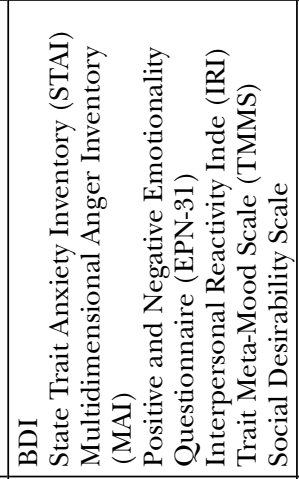 & $\mid \begin{array}{ll}0.00 \\
0.00\end{array}$ & \begin{tabular}{|l}
2.00 \\
60 \\
0.00
\end{tabular} & \\
\hline 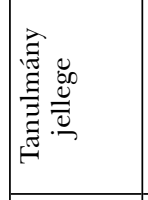 & 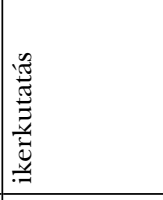 & 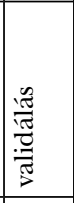 & 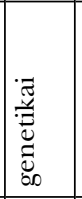 & 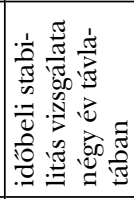 & 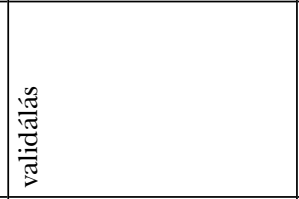 & 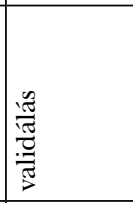 & 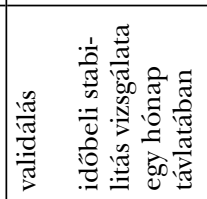 & | \\
\hline 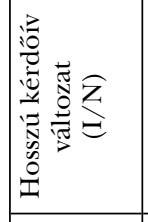 & - & - & - & 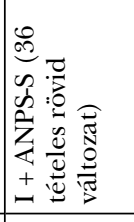 & - & - & - & - \\
\hline$\frac{z}{u}$ & 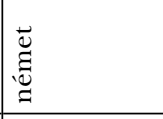 & 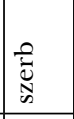 & 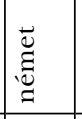 & 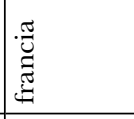 & 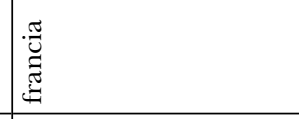 & $\begin{array}{l}: 0 \\
: 00 \\
: 0\end{array}$ & 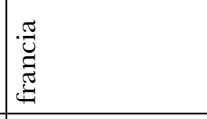 & $\frac{\tilde{n}}{\frac{\tilde{E}}{0}}$ \\
\hline 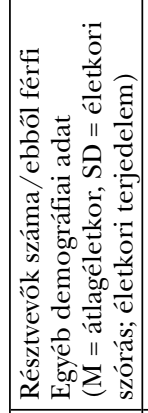 & 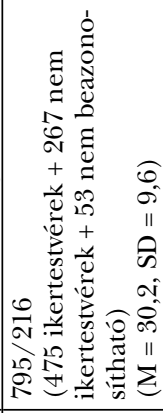 & 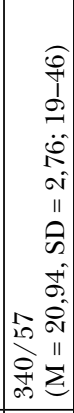 & 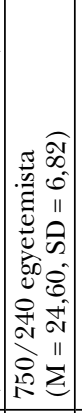 & 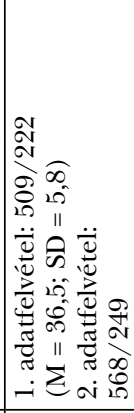 & 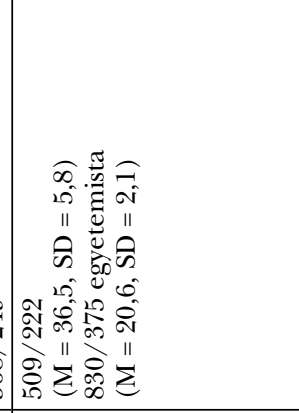 & 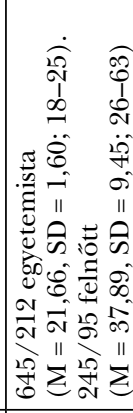 & 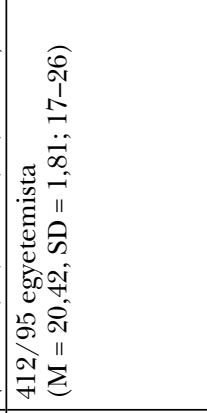 & 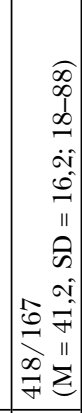 \\
\hline 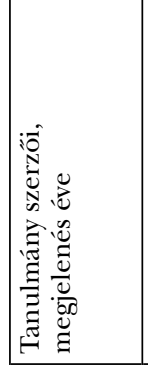 & 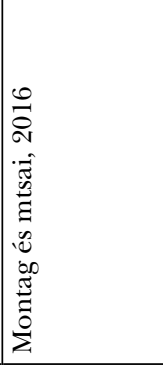 & 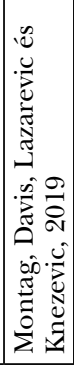 & 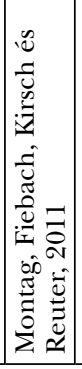 & 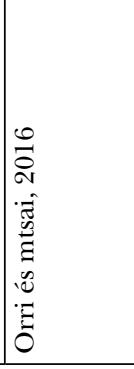 & 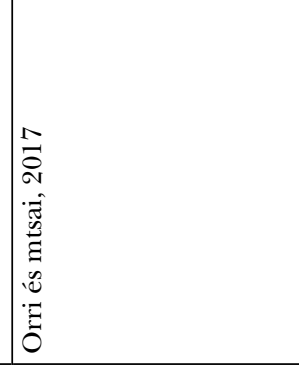 & 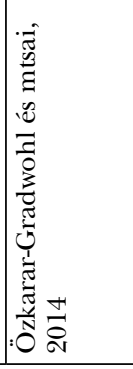 & 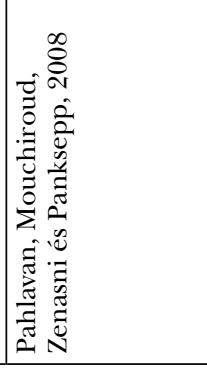 & 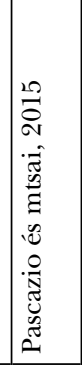 \\
\hline
\end{tabular}




\begin{tabular}{|c|c|c|c|c|c|c|c|}
\hline 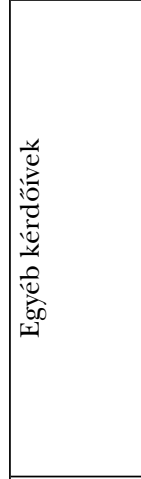 & & & 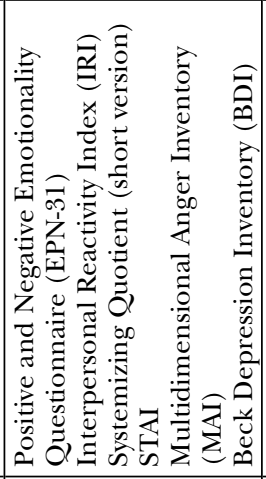 & 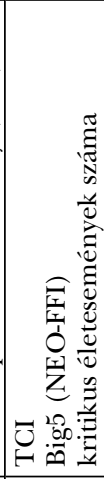 & a & 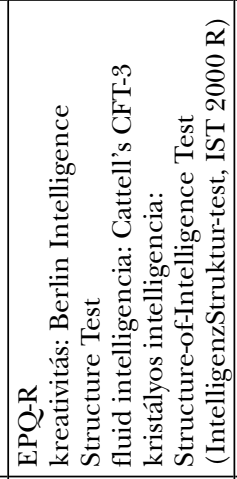 & \\
\hline 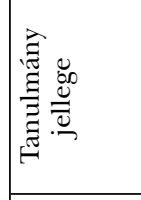 & 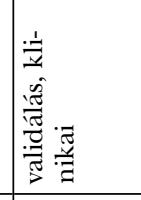 & 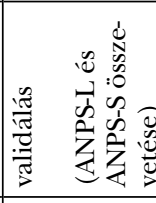 & 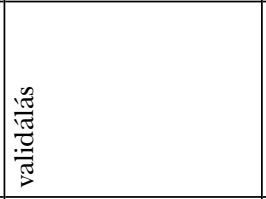 & 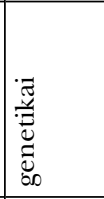 & $\overrightarrow{\underline{z}}$ & 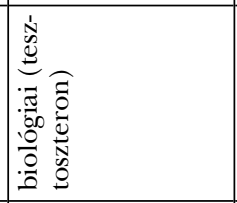 & 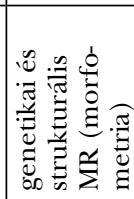 \\
\hline 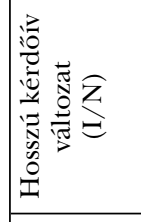 & 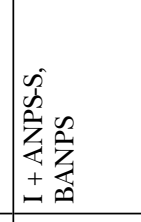 & $z$ & - & - & 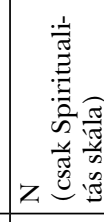 & - & 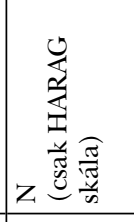 \\
\hline$\frac{\geq}{D}$ & 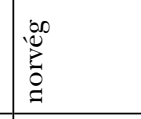 & 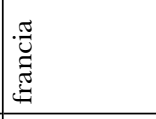 & 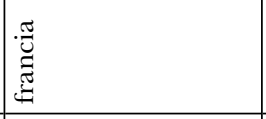 & 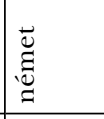 & \begin{tabular}{|l} 
\\
$\breve{\Xi}$ \\
$\stackrel{\Xi}{\Xi}$ \\
\end{tabular} & 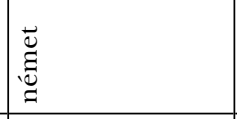 & 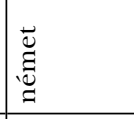 \\
\hline 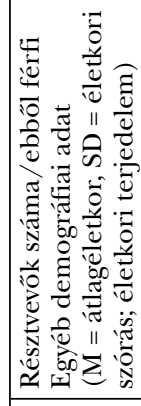 & 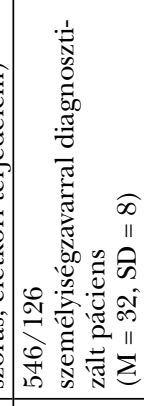 & 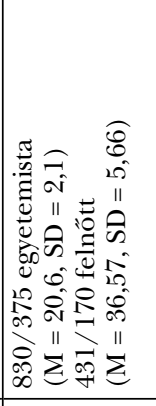 & 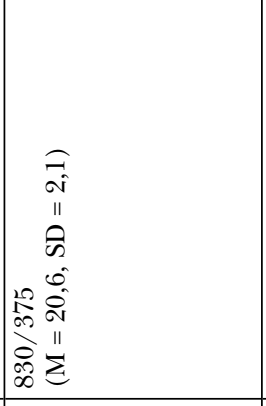 & 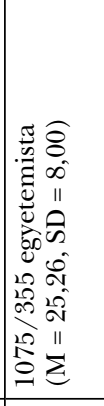 & 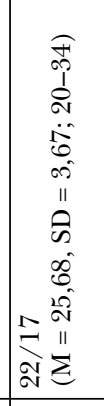 & 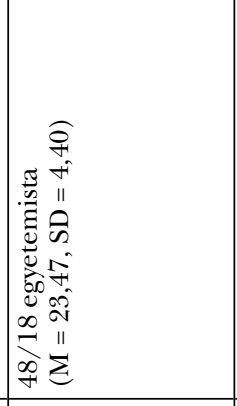 & 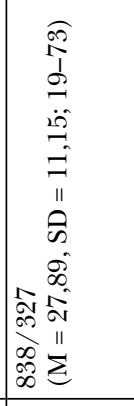 \\
\hline 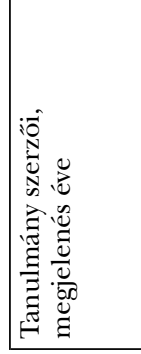 & 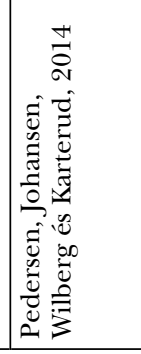 & 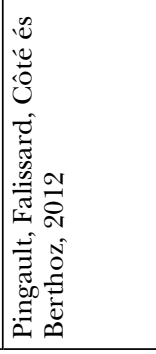 & 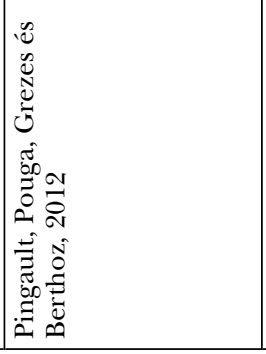 & 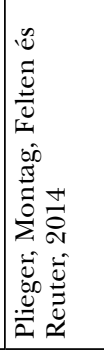 & 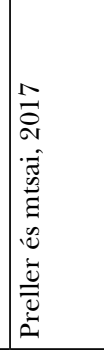 & 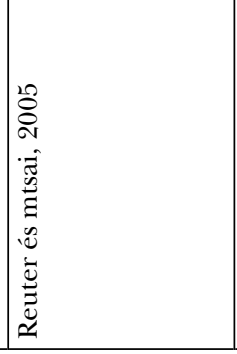 & 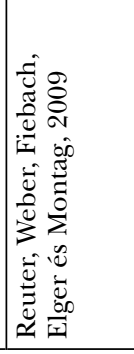 \\
\hline
\end{tabular}




\begin{tabular}{|c|c|c|c|c|c|c|c|}
\hline 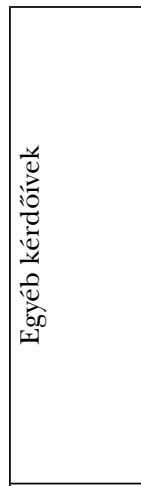 & 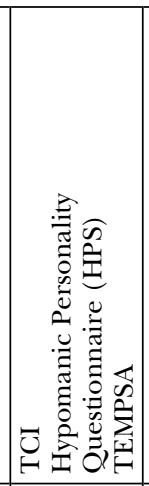 & 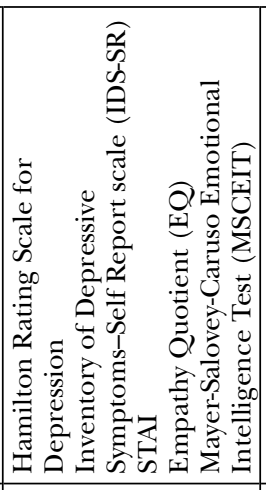 & & 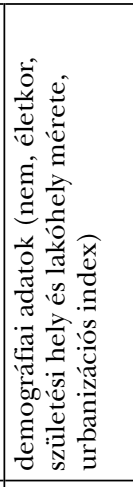 & 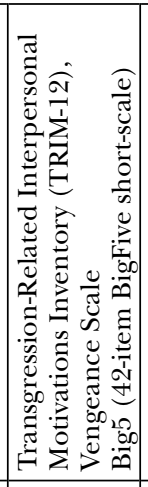 & 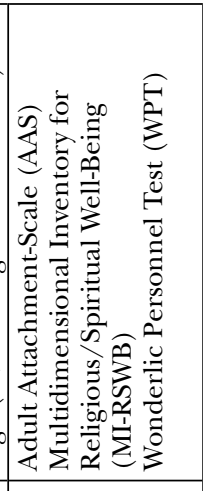 & 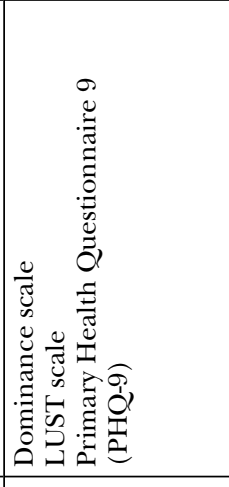 \\
\hline 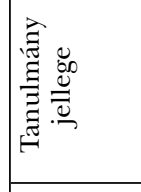 & 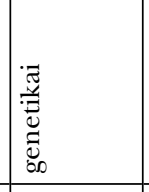 & 籴 & 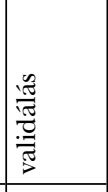 & 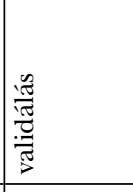 & 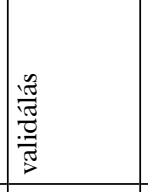 & $\vec{E}$ & 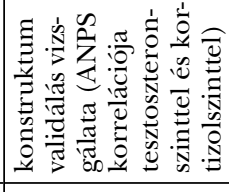 \\
\hline 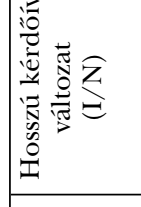 & - & - & 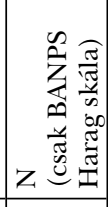 & 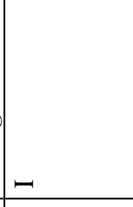 & - & $z=\begin{array}{c}\hat{n} \\
\hat{z} \\
z\end{array}$ & - \\
\hline$\frac{2}{v}$ & 总莺 & \begin{tabular}{|l|} 
\\
0 \\
0 \\
$\tilde{\sigma}$ \\
\end{tabular} & 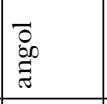 & 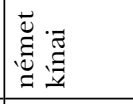 & 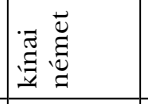 & & 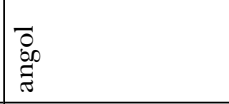 \\
\hline 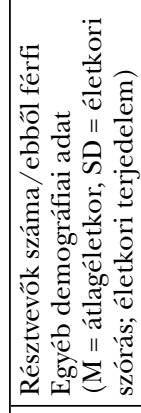 & 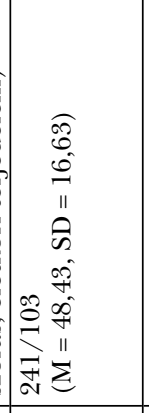 & 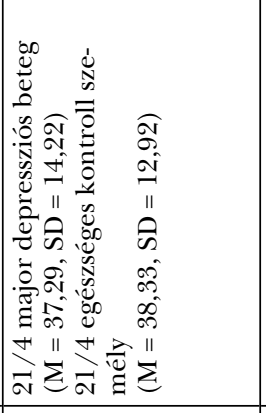 & 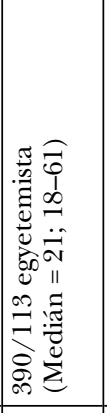 & 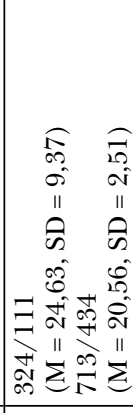 & 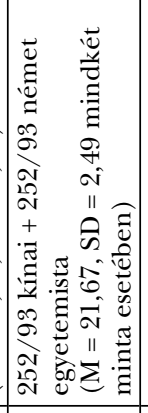 & 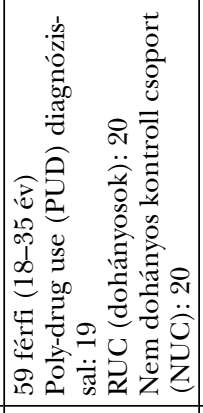 & 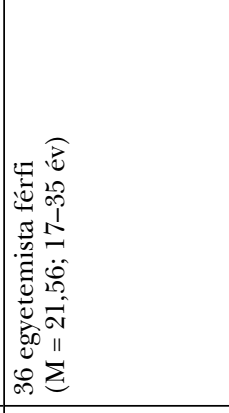 \\
\hline 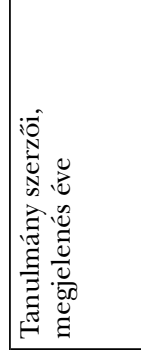 & 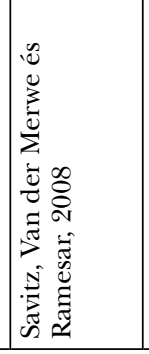 & 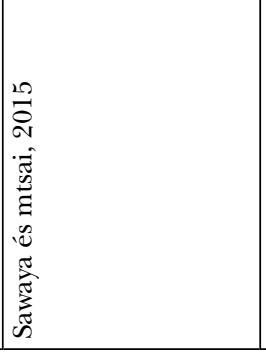 & 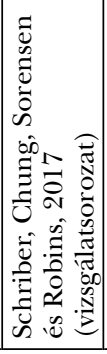 & 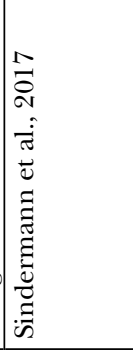 & 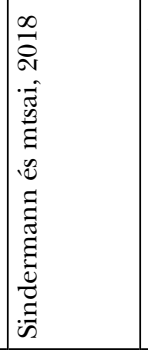 & 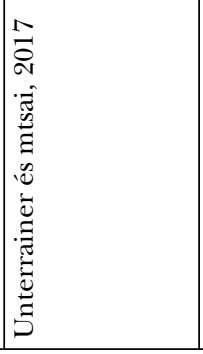 & 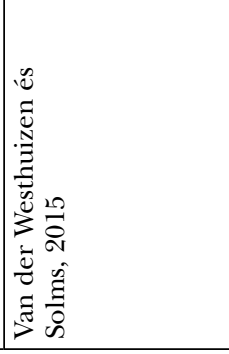 \\
\hline
\end{tabular}

